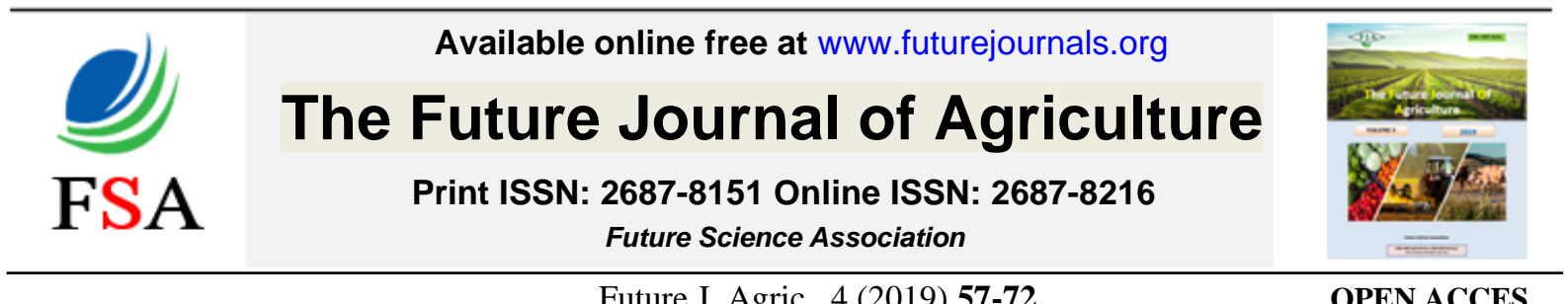

DOI: $10.37229 /$ fsa.fja.2019.12.20

Future J. Agric., 4 (2019) 57-72

OPEN ACCES

\title{
RESPONSE OF Cyperus alternifolius L. PLANT TO SOME ANTI- TRANSPIRANTS AND IRRIGATION WATER LEVELS
}

\author{
Azza M. Abd-Elmoneim1; T.M. Noor El-Deen ${ }^{1 *}$ and Gehan H. Abdel-Fattah ${ }^{2}$ \\ ${ }^{1}$ Ornamental Plants and Landscape Gardening Res. Dept., Hort. Res. Inst., ARC, Egypt. \\ ${ }^{2}$ Botanical Gardens. Res. Dept., Hort. Res. Inst., ARC, Giza, Egypt.
}

*Corresponding author: traek.noor@arc.sci.eg Received: 28 Oct. 2019 ; Accepted: 20 Dec. 2019

\begin{abstract}
This investigation was carried out in the open field at the experimental nursery of Ornamental Plants and Landscape Gardening Res. Dept., Hort. Res. Inst., ARC., Giza, Egypt during 2015/2016 and 2016/2017 seasons to study the effect of different anti-transpirants (active dry yeast extract at 1, 2 and $3 \%$, calcium carbonate at 100, 200, $300 \mathrm{ppm}$ and kaolin at 1,2 and 3\%) on umbrella plant (Cyperus alternifolius L.) cultivated as a pot plant in $25 \mathrm{~cm}$ pots under different irrigation levels expressed as percentage of water holding capacity (WHC) at $100,75,50$ and $25 \%$. The aim of this work was to reduce irrigation water quantity to a considerable level without obvious reduction in the plant quality and its aesthetic value. Reducing irrigation levels resulted in the lowering plant quality with increasing proline content (mg/g d.w.) in the plants. The effect of irrigating at $75 \%$ WHC was close to irrigating at $100 \%$ WHC without great quality reduction in most cases. Spraying with calcium carbonate $\left(\mathrm{CaCO}_{3}\right)$ at $200 \mathrm{ppm}$ or active dry yeast extract (ADY) at $3 \%$ resulted in the highest values for the most studied traits. Combined treatment between irrigating at $75 \%$ of WHC and spraying with $\mathrm{CaCO}_{3}$ at $200 \mathrm{ppm}$ produced the highest values of plant height $(\mathrm{cm})$, chlorophylls a, b, carotenoids contents (mg/g f.w.) and total carbohydrates percentage. Such treatment came in the second order after the superior combination comprised irrigating at $100 \%$ WHC without significant difference between them concerning stem number/plant, stem diameter $(\mathrm{cm})$, offset number/plant, fresh and dry weights of vegetative growth and underground parts weight $(\mathrm{g})$ and root length $(\mathrm{cm})$. Our results indicate that irrigation water quantity could be reduced by $25 \%$ without reduction in quality and atheistic value in umbrella plants planted in $25 \mathrm{~cm}$ pots via irrigation at $75 \%$ WHC two times/week and spraying them with $\mathrm{CaCO}_{3}$ at $200 \mathrm{ppm}$ monthly.
\end{abstract}

Key words: Umbrella plant, Cyperus alternifolius, irrigation amounts, anti-transpirants, active dry yeast, $\mathrm{CaCO}_{3}$, kaolin.

\section{INTRODUCTION}

Umbrella plant or umbrella palm (Cyperus alternifolius L.; Syn. $C$. involucratus) fam. Cyperaceae; native to Madagascar and widely cultivated and naturalized throughout Africa. Densely tufted perennial with woody rhizomes and no basal leaves. Reaches to $45-90 \mathrm{~cm}$ height and 40 $\mathrm{cm}$ wide. Numerous winged, dark green stems each produce a terminal whorl of 11-25 deep green, arching, leaf-like bracts, $10-15 \mathrm{~cm}$ long. From summer to autumn, the stems are topped by small spikelets of pale yellow-brown flowers in compound umbels, to $13 \mathrm{~cm}$ across. Umbrella plant is grown for its foliage and unusual inflorescences, to ensure ample moisture and high humidity at all times, containers must be stood in shallow trays of water (Brickell, 1997). Umbrella plant used as aquatic ornamental plant either outdoor or it may be grown indoors in a warm and humid environment, but the plants usually do not attain normal size (Oakes, 1990).

Water deficit is a great problem faces Egypt and other countries. According to data estimated by WWDR (2018), agriculture practices consume about $70 \%$ of effective global water withdrawals; most of it is used for irrigation. About $25 \%$ of water is lost through transpiration (Brown, 2002). Reducing water loss caused by transpiration may be an effective key to reduce water consumption.

Anti-transpirants are substances intended to reduce transpiration (Pallardy, 2008). According to its mode of action, anti-transpirants could be divided in to three general types: (1) film-forming, (2) 
stomatal-regulating and (3) reflective compounds (Brooks, 1970).

Active dry yeasts are agglomerates of dehydrated cells of Saccharomyces cerevisiae (Dobbs $\boldsymbol{e t}$ al., 1982). Dried form of yeast possesses a longer shelf life than compressed yeast and retains stability even when stored at room temperature (Deàk, 2003), so this form is suitable for using as bio-stimulants. A lot of studies proved that active dry yeast extract has a positive role on different plants when used as bio-stimulants (El-Sayed $\boldsymbol{e t}$ al., 2010 on Spathiphyllum wallisii; Abd El-Kafie et al., 2010 on tuberose; Hanafy et al., 2012 on Schefflera arboricola; El-Sayed et al., 2015 on Peperomia obtusifolia; El-Mahrouk et al., 2016 on Adhatoda vasica; El-Naggar et al., 2016 on Anthurium andreanum; Nofal et al., 2016 on Calendula officinalis; Abdel-Kader et al., 2016 on Magnolia grandiflora and Abdou et al., 2018 on Gladiolus grandiflorus). On the other hand, active dry yeast extract led to ameliorate growth characters of plants subjected to different stress conditions. In this regard Hammad and Ali (2014) stated that application of 6 $\mathrm{g} / \mathrm{l}$ of yeast extract increased all measurement studied of rice and led to overcome the deleterious effect of drought. Such positive effect of yeast extract either at normal or stress conditions may be due to its contents of essential amino acids, vitamins, cytokinins, nutrient elements and organic compounds (protein, carbohydrates, ... etc.) as reported by Barnett et al. (1990) and Nagodawithana (1991).

Calcium carbonate $\left(\mathrm{CaCO}_{3}\right)$ has been suggested by scientists as anti-transpirant. A lot of studies approved positive effect of $\mathrm{CaCO}_{3}$ on plants grown under water deficit conditions i.e. Abdel-Fattah (2013) on Hibiscus rosa-sinensis L., El-Khawaga (2013) on banana, El-Said (2015) on eggplant and Patanèet al. (2018) on tomato. Such positive effect may be obtained by the white layer formed on the leaves after spraying filters sunlight, sunburn damage due to excessive solar irradiation (Scharder, 2011).

Kaolin is a white nonabrasive fine-grained aluminosilicate mineral $\left[\mathrm{Al}_{4} \mathrm{Si}_{4} \mathrm{O}_{10}(\mathrm{OH})_{8}\right]$ that has been purified and sized so that it easily disperses in water and acts as an anti-transpirant and reducing drought stress on plants (Puterka et al., 2000). Kaolin as a particle film has long been used to limit the impact of water and heat stress on crops (Azizi $\boldsymbol{e t}$ al., 2013). Abou-Khaled et al. (1970) reported that a white leaf coating of kaolinite reduced leaf temperatures 3 to $4{ }^{\circ} \mathrm{C}$, resulting in transpiration reductions of 22 to $28 \%$ for several species. Kaolin spray was found to decrease leaf temperature by increasing leaf reflectance and to reducing transpiration rate in many plant species grown at high solar radiation levels (Nakano and Uehara, 1996).

The aim of this study was to investigate the effect of different anti-transpirants (active dry yeast, calcium carbonate and kaolin) at different concentrations on umbrella plant (Cyperus alternifolius, L.) cultivated as a pot plant under different irrigation levels. The main goal was to reduce irrigation water quantity to a considerable level without obvious reduction in the plant quality and aesthetic value.

\section{MATERIALS AND METHODS}

This investigation was carried out in the open field at the experimental nursery of Ornamental Plants and Landscape Gardening Res. Dept., Hort. Res. Inst., ARC., Giza, Egypt during 2015/2016 and 2016/2017 seasons to study the effect of different anti-transpirants (active dry yeast, calcium carbonate and kaolin) at different concentrations on umbrella plant (Cyperus alternifolius, L.) cultivated as a pot plant under different irrigation levels, and with the aim to reduce irrigation water quantity to a considerable level without obvious reduction in the plant quality and aesthetic value.

\section{Plant material}

Umbrella plant clumps were purchased from Orman Botanical Garden, Giza, Egypt on October, $20^{\text {th }}$ during both seasons. Immediately after arrived to the nursery the clumps were divided in to signal offsets with its rhizome. Homogenized offsets were selected and planted in $25 \mathrm{~cm}$-diameter-pots (one offset/pot) filled with about $1.25 \mathrm{~kg}$ of a mixture of peat-moss and sand (1:1, v:v). Pots have been irrigated sufficiently (day by day) after cultivation to ensure good establishment. After five months (March, $15^{\text {th }}$ ), the plants were ready to be subjected to the experimental treatments. The plant height was about $25 \mathrm{~cm}$ with 5 stems per plant. Chemical and physical properties of the used peat-moss are shown in Table 1.

Table 1. Some physical and chemical properties of the used peat moss in the two seasons

\begin{tabular}{llll}
\hline Organic matter & $93 \%$ & $\mathbf{K}$ & $1.77 \%$ \\
Ash & $6 \%$ & Fe & $421 \mathrm{ppm}$ \\
Density (vol. dry) & $85 \mathrm{mg} / 1$ & $\mathbf{M n}$ & $27 \mathrm{ppm}$ \\
pH value & 3.5 & $\mathbf{M g}$ & $346 \mathrm{ppm}$ \\
Water relation capacity & $68 \%$ & $\mathbf{Z n}$ & $41 \mathrm{ppm}$ \\
Salinity & $0.3 \mathrm{~g} / 1$ & $\mathbf{C u}$ & $8.8 \mathrm{ppm}$ \\
$\mathbf{N}$ & $1.09 \%$ & $\mathbf{B}$ & $3.5 \mathrm{ppm}$ \\
$\mathbf{P}$ & $0.23 \%$ & $\mathbf{M o}$ & $1.2 \mathrm{ppm}$ \\
\hline
\end{tabular}




\section{Irrigation levels}

Four irrigation levels were applied in this study based on the water holding capacity (WHC) of the used medium $(100 \%, 75 \%, 50 \%$ and $25 \%$ of WHC), water holding capacity was determined according to the method described by Brown (2002). Irrigation has been applied two times a week with a constant amount of water for each irrigation level. These amounts are shown in Table 2.

Table 2. Amount of water applied for each irrigation level ( $\mathrm{ml} / \mathrm{pot} / \mathrm{time})$

\begin{tabular}{lc}
\hline WHC level & Irrigation water quantity applied (ml/pot/time) \\
\hline $\mathbf{1 0 0 \%}$ & 314.55 \\
$\mathbf{7 5 \%}$ & 235.91 \\
$\mathbf{5 0 \%}$ & 157.28 \\
$\mathbf{2 5 \%}$ & 78.64 \\
\hline
\end{tabular}

\section{Foliar spraying with anti-transpirants}

Seven applications at one month interval were applied with each anti-transpirant each season during the course of this study; the first one was done on March, $15^{\text {th }}$. The following anti-transpirants were applied: (1) Active dry yeast extract at 1,2 and $3 \%$. It was purchased from local supermarket. (2) Calcium carbonate $\left(\mathrm{CaCO}_{3}\right)$ at 100,200 and 300 ppm. It was purchased from a local company. (3) Kaolin "aluminum silicate" $\left[\mathrm{Al}_{4} \mathrm{Si}_{4} \mathrm{O}_{10}(\mathrm{OH})_{8}\right]$ at 1,2 and 3\%, it was purchased from local Egyptian company (manufactured by LobaChemie, India). All these three anti-transpirants were dispensed in tape water to prepare the desired concentrations. The plants were sprayed with each concentration till run off. In this regard control plants were sprayed with tape water only.

\section{Experimental layout}

This experiment was designed as a completely randomized block design in a factorial experiment with two factors (Gomez and Gomez, 1984). Four irrigation levels represented factor A. While antitranspirants represented factor B with 10 treatments. Thus, total number of treatments was $40(4 \times 10)$ with three replicates per treatment and 5 plants/replicate.

\section{Data recorded}

\section{Vegetative growth parameters}

At the end of each season (last week of September) the following data were recorded; plant height $(\mathrm{cm})$, number of stems/plant (mother plant with its offsets), stem diameter $(\mathrm{cm})$, number of leaves/stem, leaf area $\left(\mathrm{cm}^{2}\right)$, vegetative growth diameter expressed as umbrella width $(\mathrm{cm})$ and vegetative growth fresh and dry weights $(\mathrm{g})$. Leaf area was calculated by using ImageJ software as described by Ferreira and Rasband (2012).

\section{Underground parts growth parameters}

Root length $(\mathrm{cm})$, number of offsets/plant and underground parts fresh and dry weights (g) including roots and rhizomes were determined at the end of each season.

\section{Chemical constituents}

At the end of the second season only the following chemical tests were done: pigments content (mg/g f.w.) as chlorophylls a, b and carotenoids was determined in fresh leaf samples according to Wellburn and Lichtenthaler (1984), total carbohydrates percentage was determined in dry leaf samples according to the method described by Herbert et al. (1971) and proline content (mg/gd.w.) was determined in dry leaf samples according to Bates et al. (1973).

\section{Statistical analysis}

The obtained data were statistically analyzed using MSTAT Computer Program (MSTAT Development Team, 1989). To verify differences among means of various treatments, means were compared using Duncan's Multiple Range Test as described by Duncan (1955).

\section{RESULTS}

\section{Vegetative growth parameters}

\section{Plant height (cm)}

As shown in Table 3, irrigating cyperus plants at either $100 \%$ or $75 \%$ WHC significantly produced the tallest plants $(47.46$ and $49.33 \mathrm{~cm}$, for the first level and 47.73 and $50.57 \mathrm{~cm}$ for the second one, in the first and second seasons respectively). Reducing irrigating level up to $25 \%$ of WHC produced the shortest plants in both seasons $(36.45$ and $38.22 \mathrm{~cm}$, respectively).

Spraying with $\mathrm{CaCO}_{3}$ at 200 ppm especially during second season significantly increased plant height $(\mathrm{cm})$ which reached the highest values in both seasons as recorded 49.53 and $52.81 \mathrm{~cm}$, respectively. Kaolin at $3 \%$ shared the previous treatment in the first season and occupied the second position $(48.33 \mathrm{~cm})$ without significant deference between both treatments.

Irrigating at $75 \% \mathrm{WHC}$ and spraying with $\mathrm{CaCO}_{3}$ at $200 \mathrm{ppm}$ significantly produced the tallest plants as recorded 61.17 and $68.69 \mathrm{~cm}$ in the first and second seasons, respectively. On the other hand irrigating at $25 \%$ WHC produced the lowest values in most possible cases (Table 3 ). 
Table 3. Effect of water irrigation level, anti-transpirant type and concentration and their interactions on plant height (cm) and stem parameters of Cyperus alternifolius L. plant during 2015/2016 and 2016/2017 seasons

\begin{tabular}{|c|c|c|c|c|c|c|c|c|c|c|}
\hline \multirow{4}{*}{$\begin{array}{l}\text { Anti- } \\
\text { transpirants }\end{array}$} & \multicolumn{5}{|c|}{ First season } & \multicolumn{5}{|c|}{ Second season } \\
\hline & \multicolumn{10}{|c|}{ Plant height (cm) } \\
\hline & \multicolumn{4}{|c|}{ WHC (\%) } & \multirow{2}{*}{ Mean } & \multicolumn{4}{|c|}{ WHC (\%) } & \multirow{2}{*}{ Mean } \\
\hline & 25 & 50 & 75 & 100 & & 25 & 50 & 75 & 100 & \\
\hline Control & 32.83 op & 33.83 op & $38.83 \mathrm{k}-\mathrm{n}$ & $42.83 \mathrm{~g}-\mathrm{k}$ & 37.08 D & $30.18 \mathrm{~s}$ & $36.61 \mathrm{p}-\mathrm{r}$ & $43.03 \mathrm{j}-\mathrm{n}$ & $49.82 \mathrm{~d}-\mathrm{h}$ & $39.91 \mathrm{E}$ \\
\hline ADY $1 \%$ & $30.17 \mathrm{p}$ & $36.331-0$ & $40.83 \mathrm{i}-1$ & $43.83 \mathrm{~g}-\mathrm{j}$ & j $37.79 \mathrm{~B}$ & $34.39 \mathrm{rs}$ & $34.93 \mathrm{rs}$ & $41.561-p$ & $44.33 \mathrm{~h}-\mathrm{n}$ & $38.80 \mathrm{E}$ \\
\hline ADY $2 \%$ & $38.83 \mathrm{k}-\mathrm{n}$ & $45.83 \mathrm{e}-\mathrm{h}$ & $51.83 \mathrm{bc}$ & $49.33 \mathrm{c}-\mathrm{e}$ & $46.46 \mathrm{~B}$ & $40.73 m-q$ & $46.46 \mathrm{~g}-1$ & $58.75 \mathrm{~b}$ & $51.38 \mathrm{~d}-\mathrm{g}$ & $49.33 \mathrm{~B}$ \\
\hline ADY 3\% & 35.17 no & $48.83 \mathrm{c}-\mathrm{f}$ & $44.33 \mathrm{f}-\mathrm{i}$ & $39.50 \mathrm{j}-\mathrm{n}$ & $41.96 \mathrm{C}$ & 37.17 o-r & $52.58 \mathrm{c}-\mathrm{e}$ & $48.41 \mathrm{e}-\mathrm{j}$ & $39.83 \mathrm{~m}-\mathrm{r}$ & r44.49 CD \\
\hline $\mathrm{CaCO}_{3} 100$ ppm & $35.67 \mathrm{~m}-\mathrm{o}$ & $39.83 \mathrm{i}-\mathrm{m}$ & $44.17 \mathrm{~g}-\mathrm{i}$ & $50.83 \mathrm{~b}-\mathrm{d}$ & $42.63 \mathrm{C}$ & $35.76 \mathrm{q}-\mathrm{s}$ & $41.101-q$ & $43.60 \mathrm{i}-\mathrm{n}$ & $50.82 \mathrm{~d}-\mathrm{g}$ & $42.82 \mathrm{D}$ \\
\hline $\mathrm{CaCO}_{3} 200$ ppm & $40.50 \mathrm{i}-1$ & $45.83 \mathrm{e}-\mathrm{h}$ & $61.17 \mathrm{a}$ & $50.60 \mathrm{~b}-\mathrm{d}$ & $49.53 \mathrm{~A}$ & $42.68 \mathrm{k}-$ & $47.66 \mathrm{e}-\mathrm{k}$ & $68.69 \mathrm{a}$ & $52.21 \mathrm{c}-\mathrm{f}$ & $52.81 \mathrm{~A}$ \\
\hline $\mathrm{CaCO}_{3} 300$ ppm & $39.50 \mathrm{j}-\mathrm{n}$ & $44.17 \mathrm{~g}-\mathrm{i}$ & $54.97 \mathrm{~b}$ & $46.83 \mathrm{~d}-\mathrm{h}$ & $46.37 \mathrm{~B}$ & $38.72 \mathrm{n}-\mathrm{r}$ & $42.47 \mathrm{k}-\mathrm{o}$ & $53.36 \mathrm{~b}-\mathrm{e}$ & $46.80 \mathrm{f}-1$ & 45.34 CD \\
\hline Kaolin 1\% & $33.17 \mathrm{op}$ & $42.50 \mathrm{~h}-\mathrm{k}$ & $43.83 \mathrm{~g}-\mathrm{j}$ & $47.17 \mathrm{~d}-\mathrm{g}$ & 41.67 C & 36.99 o-r & $42.48 \mathrm{k}-\mathrm{o}$ & $43.05 \mathrm{j}-\mathrm{n}$ & $49.08 \mathrm{e}-\mathrm{i}$ & $42.90 \mathrm{D}$ \\
\hline Kaolin 2\% & $39.17 \mathrm{k}-\mathrm{n}$ & $43.33 \mathrm{~g}-\mathrm{k}$ & $44.17 \mathrm{~g}-\mathrm{i}$ & $48.83 \mathrm{c}-\mathrm{f}$ & 43.88 C & $42.44 \mathrm{k}-\mathrm{o}$ & $44.49 \mathrm{~h}-\mathrm{m}$ & $50.29 \mathrm{~d}$ & 51.83 & $47.26 \mathrm{BC}$ \\
\hline Kaolin 3\% & $39.50 \mathrm{j}-\mathrm{n}$ & $45.83 \mathrm{e}-\mathrm{h}$ & $53.17 \mathrm{bc}$ & $54.83 \mathrm{~b}$ & 48.33A B & $43.10 \mathrm{j}-\mathrm{n}$ & $43.85 \mathrm{i}-\mathrm{n}$ & $54.94 \mathrm{~b}-\mathrm{d}$ & $57.22 \mathrm{bc}$ & 49.78 B \\
\hline \multirow[t]{2}{*}{ Mean } & $36.45 \mathrm{C}$ & $42.63 \mathrm{~B}$ & $47.73 \mathrm{~A}$ & $47.46 \mathrm{~A}$ & & $38.22 \mathrm{C}$ & 43.26 B & 50.57 A & $49.33 \mathrm{~A}$ & \\
\hline & \multicolumn{10}{|c|}{ Number of stems/plant } \\
\hline Control & $12.00 \mathrm{u}$ & $14.00 \mathrm{~s}-\mathrm{u}$ & $18.671-$ & $25.00 \mathrm{e}-\mathrm{h}$ & $17.42 \mathrm{G}$ & $12.69 \mathrm{t}$ & $15.42 \mathrm{p}-\mathrm{s}$ & 1830 & 2502 & \\
\hline ADY $1 \%$ & $15.00 \mathrm{r}-\mathrm{t}$ & $16.00 \mathrm{p}-\mathrm{s}$ & $20.33 \mathrm{j}-1$ & $24.67 \mathrm{e}$ & $19.00 \mathrm{EF}$ & $13.29 \mathrm{r}-\mathrm{t}$ & $16.48 \mathrm{n}-\mathrm{q}$ & $21.01 \mathrm{~J}-1$ & $24.08 \mathrm{~g}-\mathrm{j}$ & $18.88 \mathrm{E}$ \\
\hline ADY $2 \%$ & $16.00 \mathrm{p}-\mathrm{s}$ & $19.001-0$ & $20.33 \mathrm{j}-\mathrm{m}$ & $26.67 \mathrm{~d}-\mathrm{f}$ & 20.50 CD & $14.37 \mathrm{q}-\mathrm{t}$ & $20.07 \mathrm{~lm}$ & $22.19 \mathrm{i}-1$ & $27.97 \mathrm{de}$ & 21.15 D \\
\hline ADY 3\% & 17.17 n-r & $19.67 \mathrm{k}-\mathrm{n}$ & $20.67 \mathrm{i}-\mathrm{m}$ & $27.33 \mathrm{c}$ & $21.21 \mathrm{CD}$ & $16.40 n-$ & $20.27 \mathrm{~lm}$ & $27.01 \mathrm{~d}-\mathrm{f}$ & $30.87 \mathrm{bc}$ & 23.64 C \\
\hline $\mathrm{CaCO}_{3} 100$ ppm & $15.67 \mathrm{q}-\mathrm{s}$ & $18.00 \mathrm{~m}-\mathrm{q}$ & $24.00 \mathrm{f}-\mathrm{h}$ & $29.00 \mathrm{~cd}$ & 21.67 C & $16.98 n-p$ & $20.51 \mathrm{k}-\mathrm{m}$ & $22.08 \mathrm{i}-1$ & $29.27 \mathrm{~cd}$ & 22.21 D \\
\hline $\mathrm{CaCO}_{3} 200$ ppm & $22.67 \mathrm{~g}-\mathrm{j}$ & $25.33 \mathrm{e}-\mathrm{g}$ & $32.00 \mathrm{ab}$ & $27.00 \mathrm{de}$ & $26.75 \mathrm{~A}$ & $25.57 \mathrm{e}-\mathrm{g}$ & $24.98 \mathrm{f}-\mathrm{h}$ & $35.07 \mathrm{a}$ & $32.50 \mathrm{~b}$ & $29.53 \mathrm{~A}$ \\
\hline $\mathrm{CaCO}_{3} 300$ ppm & $19.331-0$ & $24.00 \mathrm{f}-\mathrm{h}$ & $30.00 \mathrm{bc}$ & $29.00 \mathrm{~cd}$ & $25.58 \mathrm{~A}$ & $19.91 \mathrm{~lm}$ & $22.94 \mathrm{~h}-\mathrm{k}$ & $32.33 \mathrm{~b}$ & $27.62 \mathrm{de}$ & $25.70 \mathrm{~B}$ \\
\hline Kaolin 1\% & $12.70 \mathrm{tu}$ & $14.67 \mathrm{r}-\mathrm{u}$ & $20.04 j-n$ & $23.33 \mathrm{~g}-\mathrm{i}$ & 17.68 FG & $13.22 \mathrm{st}$ & $13.52 \mathrm{r}-\mathrm{t}$ & $20.73 \mathrm{k}-\mathrm{m}$ & $21.91 \mathrm{i}-1$ & $17.35 \mathrm{~F}$ \\
\hline Kaolin 2\% & $16.67 \mathrm{o}-\mathrm{s}$ & $19.67 \mathrm{k}-\mathrm{n}$ & $34.33 \mathrm{a}$ & 22.33 h-k & $23.25 \mathrm{~B}$ & $18.23 \mathrm{~m}-\mathrm{o}$ & $20.51 \mathrm{k}-\mathrm{m}$ & $35.95 \mathrm{a}$ & $24.22 \mathrm{~g}-\mathrm{i}$ & $24.73 \mathrm{BC}$ \\
\hline Kaolin 3\% & $15.00 \mathrm{r}-\mathrm{t}$ & $26.33 \mathrm{~d}-\mathrm{f}$ & $21.00 \mathrm{i}-1$ & $18.00 \mathrm{~m}-\mathrm{q}$ & 20.08 DE & 15.76 o-r & $28.33 \mathrm{~cd}$ & $21.95 \mathrm{i}-1$ & $18.37 \mathrm{mn}$ & $21.10 \mathrm{D}$ \\
\hline \multirow[t]{2}{*}{ Mean } & 16.22 D & 19.67 C & 24.14 B & $25.23 \mathrm{~A}$ & & 16.64 C & $20.30 \mathrm{~B}$ & $25.74 \mathrm{~A}$ & $26.18 \mathrm{~A}$ & \\
\hline & \multicolumn{10}{|c|}{ Stem diameter $(\mathrm{cm})$} \\
\hline Control & 0.57 op & $0.77 \mathrm{i}-\mathrm{m}$ & $0.83 \mathrm{~g}-\mathrm{k}$ & $0.90 \mathrm{f}-\mathrm{i}$ & 0.77 DE & $0.59 \mathrm{~s}$ & $0.74 \mathrm{n}-\mathrm{s}$ & $0.92 \mathrm{~h}-\mathrm{m}$ & $1.04 \mathrm{~d}-\mathrm{h}$ & 0.82 \\
\hline ADY $1 \%$ & $0.671-0$ & $0.77 \mathrm{i}-\mathrm{m}$ & 0.80 h-l & $0.97 \mathrm{e}-\mathrm{g}$ & $0.80 \mathrm{CD}$ & $0.66 \mathrm{q}-\mathrm{s}$ & $0.74 \mathrm{n}-\mathrm{s}$ & $0.84 \mathrm{j}-\mathrm{p}$ & $0.99 \mathrm{e}-\mathrm{k}$ & $0.81 \mathrm{CD}$ \\
\hline ADY $2 \%$ & $0.70 \mathrm{k}-\mathrm{o}$ & $0.80 \mathrm{~h}-1$ & $0.97 \mathrm{e}-\mathrm{g}$ & $1.17 \mathrm{a}-\mathrm{c}$ & $0.91 \mathrm{~B}$ & $0.76 \mathrm{~m}-\mathrm{r}$ & $0.801-q$ & $0.99 \mathrm{e}-\mathrm{k}$ & $1.19 \mathrm{~cd}$ & $0.94 \mathrm{~B}$ \\
\hline ADY 3\% & $0.77 \mathrm{i}-\mathrm{m}$ & $0.80 \mathrm{~h}-1$ & $1.13 \mathrm{~b}-\mathrm{d}$ & $1.30 \mathrm{a}$ & $1.00 \mathrm{~A}$ & $0.83 \mathrm{k}-\mathrm{q}$ & $0.93 \mathrm{~h}-\mathrm{m}$ & $1.11 \mathrm{c}-\mathrm{g}$ & $1.58 \mathrm{a}$ & $1.11 \mathrm{~A}$ \\
\hline $\mathrm{CaCO}_{3} 100$ ppm & 0.57 op & $0.77 \mathrm{i}-\mathrm{m}$ & 0.80 h-1 & $0.97 \mathrm{e}-\mathrm{g}$ & $0.78 \mathrm{E}$ & $0.39 \mathrm{t}$ & $0.68 \mathrm{o}-\mathrm{s}$ & 0.89 h-n & $1.01 \mathrm{e}-\mathrm{i}$ & $0.74 \mathrm{D}$ \\
\hline $\mathrm{CaCO}_{3} 200$ ppm & $0.73 \mathrm{j}-\mathrm{n}$ & $0.83 \mathrm{~g}-\mathrm{k}$ & $1.27 \mathrm{ab}$ & $1.20 \mathrm{a}-\mathrm{c}$ & $1.01 \mathrm{~A}$ & $0.99 \mathrm{e}-\mathrm{k}$ & $1.16 \mathrm{c}-\mathrm{e}$ & $1.36 \mathrm{~b}$ & $1.12 \mathrm{c}-\mathrm{g}$ & $1.16 \mathrm{~A}$ \\
\hline $\mathrm{CaCO}_{3} 300$ ppm & $0.61 \mathrm{n}-\mathrm{p}$ & $0.80 \mathrm{~h}-1$ & $1.17 \mathrm{a}-\mathrm{c}$ & $0.90 \mathrm{f}-\mathrm{i}$ & $0.87 \mathrm{BC}$ & $0.62 \mathrm{rs}$ & $0.85 \mathrm{i}-\mathrm{o}$ & $1.13 \mathrm{c}-\mathrm{f}$ & $0.92 \mathrm{~h}-\mathrm{m}$ & $0.88 \mathrm{BC}$ \\
\hline Kaolin 1\% & $0.60 \mathrm{n}-\mathrm{p}$ & $0.73 \mathrm{j}-\mathrm{n}$ & $0.87 \mathrm{f}-\mathrm{j}$ & $0.97 \mathrm{e}-\mathrm{g}$ & 0.79 C-E & $0.57 \mathrm{~s}$ & $0.70 \mathrm{o}-\mathrm{s}$ & $0.94 \mathrm{~h}-1$ & $1.02 \mathrm{~d}-\mathrm{h}$ & 0.81 CD \\
\hline Kaolin 2\% & $0.97 \mathrm{e}-\mathrm{g}$ & $0.97 \mathrm{e}-\mathrm{g}$ & $1.27 \mathrm{ab}$ & $1.00 \mathrm{~d}-\mathrm{f}$ & $1.05 \mathrm{~A}$ & $0.95 \mathrm{~g}-1$ & $1.01 \mathrm{e}-\mathrm{j}$ & $1.39 \mathrm{~b}$ & $1.05 \mathrm{~d}-\mathrm{h}$ & $1.10 \mathrm{~A}$ \\
\hline Kaolin 3\% & $0.63 \mathrm{~m}-\mathrm{p}$ & $1.10 \mathrm{c}-\mathrm{e}$ & $0.93 \mathrm{f}-\mathrm{h}$ & $0.83 \mathrm{~g}-\mathrm{k}$ & 0.88 B & $0.67 \mathrm{p}-\mathrm{s}$ & $1.28 \mathrm{bc}$ & $0.98 \mathrm{f}-\mathrm{k}$ & $0.90 \mathrm{~h}-\mathrm{n}$ & 0.96 B \\
\hline Mean & $0.68 \mathrm{C}$ & $0.83 \mathrm{~B}$ & $1.00 \mathrm{~A}$ & $1.02 \mathrm{~A}$ & & $0.70 \mathrm{C}$ & $0.89 \mathrm{~B}$ & $1.06 \mathrm{~A}$ & $1.08 \mathrm{~A}$ & \\
\hline
\end{tabular}

Means having the same letter within a column or rows are not significantly differed at 0.05 level of probability according to Duncan's multiple range test. 


\section{Number of stems}

Data presented in Table 3 indicate that irrigating cyperus plants at $100 \%$ WHC significantly resulted in the highest values in terms of stems number ( 25.23 and $26.18 \mathrm{~cm}$, in the first and second seasons, respectively). This was followed by irrigating at $75 \%$ WHC in both seasons, without significant difference between them in the second season only (24.14 and 25.74 stems/plant in both seasons, respectively).

Spraying with $\mathrm{CaCO}_{3}$ at either 200 or 300 ppm significantly increased stem number to the maximum values in the first season as recorded 26.75 and 25.58, respectively. In the second season, the mastery was to spraying with $\mathrm{CaCO}_{3}$ at $200 \mathrm{ppm}$ which resulted in the highest significant number 29.53 .

Irrigating at $75 \% \mathrm{WHC}$ and spraying plants with either kaolin at $2 \%$ or $\mathrm{CaCO}_{3}$ at $200 \mathrm{ppm}$ produced the highest significant values as recorded 34.33 and $32.00 \mathrm{~cm}$ in the first season and 35.95 and 35.07 in the second one, respectively. On the other hand, irrigating at $25 \%$ WHC produced the lowest values in most cases when combined with any applied antitranspirants (Table 3 ).

\section{Stem diameter $(\mathrm{cm})$}

Table 3 shows that irrigating cyperus plants at either $100 \%$ or $75 \%$ WHC produced the thickest stems $(1.02$ and $1.08 \mathrm{~cm}$, for the first level and 1.00 and $1.06 \mathrm{~cm}$ for the second one, in the first and second seasons, respectively). Reducing irrigating level up to $25 \%$ of WHC produced the lowest values in both seasons ( 0.68 and $0.70 \mathrm{~cm}$, respectively).

It could be noticed that spraying with either kaolin at $2 \%, \mathrm{CaCO}_{3}$ at $200 \mathrm{ppm}$ or active dry yeast extract at 3\% resulted in the highest significant values of stem diameter without significant differences between them. In this regard, spraying with kaolin at $2 \%$ produced the highest value in the first season $(1.05 \mathrm{~cm})$ while $\mathrm{CaCO}_{3}$ at $200 \mathrm{ppm}$ produced the highest value in the second one (1.16 $\mathrm{cm})$.

Irrigating at $100 \%$ WHC and spraying with active dry yeast extract at 3\% resulted in the highest values of stem diameter as recorded $1.30 \mathrm{~cm}$ and $1.58 \mathrm{~cm}$ in the first and second seasons, respectively. Many other combined treatments shared the previous mentioned treatment without significant differences between them i.e. irrigating at $75 \%$ WHC in addition to spraying with either $\mathrm{CaCO}_{3}$ at $200 \mathrm{ppm}(1.27 \mathrm{~cm})$ or kaolin at $2 \%(1.27 \mathrm{~cm})$. On the other hand irrigating at $25 \%$ WHC produced the lowest values in most possible cases when combined with any of anti-transpirants (Table 3).

\section{Number of leaves/stem}

Data tabulated in Table 4 indicate that irrigating cyperus plants at either $100 \%$ or $75 \%$ WHC produced the highest significant number of leaves (17.90 and 19.03, for the first level and 17.84 and 18.84 for the second one, in the first and second seasons, respectively). Reducing irrigating level up to $25 \%$ of WHC produced the lowest values in both seasons (13.20 and 13.17, respectively).

It could be noticed that spraying with either kaolin at $2 \%$ or active dry yeast extract at $3 \%$ resulted in the highest significant values of number of leaves/stem without significant differences between them in the first season (18.08 and 17.53, respectively). While, in the second season the mastery was to the two previous mentioned treatments in addition to spraying with $\mathrm{COCa}_{3}$ at 200 ppm (19.03, 18.77 and 18.77, respectively) without significant differences among these treatments.

Irrigating at $75 \% \mathrm{WHC}$ in addition to spraying with either $\mathrm{CaCO}_{3}$ at $200 \mathrm{ppm}$ and kaolin at $2 \%$ resulted in the highest significant values in number of leaves/stem as recorded 20.33 and 20.33 in the first season and 22.73 and 22.03 in the second one, respectively. Many other combined treatments shared the previous mentioned treatment without significant differences among them i.e. irrigating at $100 \%$ WHC in addition to spraying with active dry yeast extract at 3\% (20.00 and 21.95 in both seasons, respectively).On the other hand, irrigating at $25 \%$ WHC produced the lowest values in most cases when combined with any of anti-transpirants (Table 4).

\section{Leaf area $\left(\mathrm{cm}^{2}\right)$}

With the reference to Table 4, irrigating cyperus plants at $100 \%$ WHC resulted in the highest significant leaf area values $\left(19.89\right.$ and $20.51 \mathrm{~cm}^{2}$, in the first and second seasons respectively). This was followed by irrigating at 75\% WHC in both seasons (18.68 and $19.66 \mathrm{~cm}^{2}$, respectively), with significant difference between them in both seasons. On the other hand, the lowest values, were obtained by irrigating at 25\% WHC as recorded 11.41 and 11.88 $\mathrm{cm}^{2}$ in both seasons, respectively.

Active dry yeast extract at $3 \%$ recorded the highest values of leaf area (21.81 and $22.59 \mathrm{~cm}^{2}$ in both seasons, respectively). Spraying with $\mathrm{CaCO}_{3}$ at $200 \mathrm{ppm}$ occupied the second position in both seasons as recorded 19.76 and $21.55 \mathrm{~cm}^{2}$, respectively.

Irrigating at $75 \%$ WHC in addition to spraying with active dry yeast extract at 3\% produced the highest leaf area in both seasons (29.14 and 30.61 $\mathrm{cm}^{2}$, respectively). In this regard irrigating at $100 \%$ WHC in addition to spraying with $\mathrm{CaCO}_{3}$ at 200 ppm shared the previous mentioned treatment in the second season only as recorded $29.89 \mathrm{~cm}^{2}$ without significant differences between them. On the other hand all combinations included irrigating at 25\% WHC resulted in the lowest values (Table 4). 
Table 4. Effect of water irrigation level, anti-transpirant type and concentration and their interactions on leaves parameter and umbrella width (cm) of Cyperus alternifolius L. plants during 2015/2016 and 2016/2017 seasons

\begin{tabular}{|c|c|c|c|c|c|c|c|c|c|c|}
\hline \multirow{4}{*}{$\begin{array}{l}\text { Irrigation } \\
\text { level } \\
\text { Anti- } \\
\text { transpirants }\end{array}$} & \multicolumn{5}{|c|}{ First season } & \multicolumn{5}{|c|}{ Second season } \\
\hline & \multicolumn{10}{|c|}{ Number of leaves/stem } \\
\hline & \multicolumn{4}{|c|}{ WHC (\%) } & \multirow{2}{*}{ Mean } & \multicolumn{4}{|c|}{ WHC (\%) } & \multirow{2}{*}{ Mean } \\
\hline & 25 & 50 & 75 & 100 & & 25 & 50 & 75 & & \\
\hline Control & $10.99 q$ & 14.67 no & $16.00 \mathrm{j}-\mathrm{n}$ & $17.33 \mathrm{f}-\mathrm{j}$ & $14.75 \mathrm{E}$ & $10.75 \mathrm{t}$ & $13.76 \mathrm{q}$ & $15.64 \mathrm{~m}-\mathrm{o}$ & $17.47 \mathrm{ij}$ & \\
\hline ADY $1 \%$ & $12.33 \mathrm{pq}$ & 14.67 no & $16.00 \mathrm{j}-\mathrm{n}$ & $17.33 \mathrm{f}-\mathrm{j}$ & $15.08 \mathrm{E}$ & $11.75 \mathrm{~s}$ & $13.83 \mathrm{q}$ & $15.74 \mathrm{mn}$ & $17.89 \mathrm{~g}-\mathrm{j}$ & \\
\hline ADY $2 \%$ & 13.67 op & $15.441-n$ & $17.67 \mathrm{e}-\mathrm{i}$ & 19.67 a-c 1 & 16.61 CD & $14.40 \mathrm{pq}$ & $15.35 \mathrm{no}$ & $18.30 \mathrm{f}-\mathrm{h}$ & $19.44 \mathrm{de}$ & \\
\hline ADY 3\% & 14.67 no & $16.67 \mathrm{~h}-1$ & $18.78 \mathrm{~b}-\mathrm{f}$ & $20.00 \mathrm{ab} 1$ & $17.53 \mathrm{AB}$ & 15.39 no & $17.82 \mathrm{~g}-\mathrm{j}$ & $19.94 \mathrm{~cd}$ & $21.95 \mathrm{a}$ & \\
\hline $\mathrm{CaCO}_{3} 100$ ppm & $11.00 \mathrm{q}$ & $15.67 \mathrm{k}-\mathrm{n}$ & & $17.67 \mathrm{e}-\mathrm{i}$ & & $10.82 \mathrm{t}$ & $15.51 \mathrm{no}$ & $17.64 \mathrm{~h}-\mathrm{j}$ & $19.50 \mathrm{de}$ & \\
\hline $\mathrm{CaCO}_{3} 200$ ppm & $15.00 \mathrm{~m}-\mathrm{o}$ & $16.00 \mathrm{j}-\mathrm{n}$ & $20.33 \mathrm{a}$ & $18.00 \mathrm{~d}-\mathrm{h} 1$ & 17.33 BC & $14.52 \mathrm{pq}$ & $17.72 \mathrm{~h}-\mathrm{j}$ & $22.73 \mathrm{a}$ & $20.11 \mathrm{~cd}$ & \\
\hline $\mathrm{CaCO}_{3} 300$ ppm & $12.67 \mathrm{p}$ & $16.00 \mathrm{j}-\mathrm{n}$ & $19.33 \mathrm{a}-\mathrm{d}$ & $17.00 \mathrm{~g}-\mathrm{k}$ & & $12.77 \mathrm{r}$ & $16.60 \mathrm{kl}$ & $21.03 \mathrm{~b}$ & $18.91 \mathrm{ef}$ & 3 B \\
\hline Kaolin 1\% & $11.00 \mathrm{q}$ & 14.67 no & $16.67 \mathrm{~h}-1$ & $18.33 \mathrm{c}-\mathrm{g}$ & $15.17 \mathrm{E}$ & $11.72 \mathrm{~s}$ & 14.88 op & $17.19 \mathrm{jk}$ & $18.62 \mathrm{fg}$ & $15.60 \mathrm{D}$ \\
\hline Caolin 2\% & $17.00 \mathrm{~g}-\mathrm{k}$ & $17.00 \mathrm{~g}-\mathrm{k}$ & $20.33 \mathrm{a}$ & $18.00 \mathrm{~d}-\mathrm{h}$ & & $15.841-n$ & $18.27 \mathrm{f}-\mathrm{i}$ & $22.03 \mathrm{a}$ & $19.96 \mathrm{~cd}$ & \\
\hline Kaolin 3\% & 13.67 op & 19.00 a-e & $17.00 \mathrm{~g}-\mathrm{k}$ & $15.67 \mathrm{k}-\mathrm{n}$ & $16.33 \mathrm{D}$ & $13.70 \mathrm{q}$ & $20.67 \mathrm{bc}$ & $18.14 \mathrm{f}-\mathrm{i}$ & $16.44 \mathrm{k}-\mathrm{m} 1$ & $\mathrm{BC}$ \\
\hline \multirow[t]{2}{*}{ Mean } & $13.20 \mathrm{C}$ & $15.98 \mathrm{~B}$ & $17.84 \mathrm{~A}$ & $17.90 \mathrm{~A}$ & & $13.17 \mathrm{C}$ & 16.44 B & $18.84 \mathrm{~A}$ & $19.03 \mathrm{~A}$ & \\
\hline & \multicolumn{10}{|c|}{ Leaf area $(\mathrm{cm} 2)$} \\
\hline Control & $7.89 \mathrm{r}$ & $12.10 \mathrm{n}-\mathrm{p}$ & $1-0$ & & & $9.35 \mathrm{st}$ & $13.32 \mathrm{n}-\mathrm{q}$ & -4 & & \\
\hline Y $1 \%$ & $8.55 \mathrm{r}$ & $12.30 \mathrm{n}-\mathrm{p}$ & $15.98 \mathrm{~g}-\mathrm{k}$ & $16.24 \mathrm{~g}-\mathrm{j}$ & $13.27 \mathrm{E}$ & $9.85 \mathrm{st}$ & $12.61 \mathrm{p}-\mathrm{r}$ & $1555 \mathrm{i} m$ & $17.59 \mathrm{f}-\mathrm{h}$ & $0 \mathbf{E}$ \\
\hline ADY 2\% & 13.18 l-o & $14.84 \mathrm{i}-1$ & $17.91 \mathrm{fg}$ & $24.82 \mathrm{c}$ & $17.69 \mathrm{C}$ & 12.98 o-r & $16.29 \mathrm{~h}-\mathrm{k}$ & $19.37 \mathrm{ef}$ & $25.78 \mathrm{~b}$ & $60 \mathrm{C}$ \\
\hline ADY 3\% & $15.25 \mathrm{~h}-\mathrm{k}$ & $19.79 \mathrm{~d}-\mathrm{f}$ & $29.14 \mathrm{a}$ & $23.04 \mathrm{c}$ & $21.81 \mathrm{~A}$ & $14.72 \mathrm{j}-\mathrm{o}$ & $20.39 \mathrm{de}$ & $30.61 \mathrm{a}$ & $24.64 \mathrm{bc}$ & $9 \mathrm{~A}$ \\
\hline $\mathrm{CaCO}_{3} 100$ ppm & $9.39 \mathrm{qr}$ & $14.32 \mathrm{j}-\mathrm{m}$ & $16.79 \mathrm{~g}-\mathrm{i}$ & $19.61 \mathrm{~d}-\mathrm{f}$ & 15.03 D & $9.14 \mathrm{t}$ & $15.00 \mathrm{j}-\mathrm{n}$ & $17.11 \mathrm{~g}-\mathrm{i}$ & $19.85 \mathrm{de}$ & 15.27 D \\
\hline $\mathrm{CaCO}_{3} 200$ ppm & $14.40 \mathrm{j}-\mathrm{m}$ & $16.98 \mathrm{gh}$ & $20.74 \mathrm{de}$ & $26.93 \mathrm{~b}$ & $19.76 \mathrm{~B}$ & $15.66 \mathrm{i}-1$ & $18.91 \mathrm{e}-\mathrm{g}$ & $21.72 \mathrm{~d}$ & $29.89 \mathrm{a}$ & 55 B \\
\hline $\mathrm{CaCO}_{3} 300$ ppm & 11.83 op & $16.13 \mathrm{~g}-\mathrm{j}$ & $24.35 \mathrm{c}$ & $21.01 \mathrm{~d}$ & $18.33 \mathrm{C}$ & $12.05 \mathrm{qr}$ & $17.22 \mathrm{~g}-\mathrm{i}$ & $25.43 \mathrm{bc}$ & $20.80 \mathrm{de}$ & $18.88 \mathrm{C}$ \\
\hline Kaolin 1\% & $8.45 \mathrm{r}$ & $8.63 \mathrm{qr}$ & $12.66 \mathrm{~m}-\mathrm{o}$ & 18.99 ef & $12.18 \mathrm{~F}$ & $9.42 \mathrm{st}$ & $9.47 \mathrm{st}$ & $13.05 \mathrm{o}-\mathrm{r}$ & $16.99 \mathrm{hi}$ & $12.23 \mathrm{~F}$ \\
\hline Kaolin 2\% & $14.63 \mathrm{j}-1$ & $16.84 \mathrm{gh}$ & $19.98 \mathrm{de}$ & $19.78 \mathrm{~d}-\mathrm{f}$ & $1 \% .01 \mathrm{C}$ & $14.37 \mathrm{k}-\mathrm{p}$ & $17.66 \mathrm{f}-\mathrm{h}$ & $23.69 \mathrm{c}$ & $19.86 \mathrm{de}$ & $18.90 \mathrm{C}$ \\
\hline Kaolin 3\% & $10.54 \mathrm{pq}$ & 19.04 ef & $16.18 \mathrm{~g}-\mathrm{j}$ & $14.37 \mathrm{j}-\mathrm{m}$ & $15.03 \mathrm{D}$ & $11.21 \mathrm{rs}$ & $21.54 \mathrm{~d}$ & $16.38 \mathrm{~h}-\mathrm{j}$ & $14.371-p$ & $15.87 \mathrm{D}$ \\
\hline Mean & 11.41 D & $15.10 \mathrm{C}$ & 18.68 B & $19.89 \mathrm{~A}$ & & 11.88 D & 16.24 C & 19.66 B & $20.51 \mathrm{~A}$ & \\
\hline
\end{tabular}

Umbrella width (cm)

Control 29.67 n-p 30.50m-p 33.00 i-n 35.67 g-k 32.21 G 27.06 r 33.17m-p 35.73 1-o 37.20 j-m 33.29 G

ADY 1\% 29.83m-p 31.83 k-n 35.17 g-1 40.83 b-e 34.42 EF 29.66 p-r 33.50m-p 39.36 i-l 41.26 d-j 35.95 EF

ADY 2\% $\quad 30.00 m-p ~ 32.67$ i-n 40.50 b-f 44.33 ab 36.88 CD 31.94 o-q 35.85 1-o 40.43 e-k 48.44 a-c 39.16 CD

ADY 3\% $\quad 32.50$ j-n 38.17 d-g 41.50 b-d 47.67 a 39.96 AB 33.11m-p 39.43 h-l 44.40 c-f 50.86 a 41.95 AB

$\mathbf{C a C O}_{3} 100$ ppm 26.67 p 31.50 k-n 37.50 d-g 41.00 b-e 34.17E-G 26.90 r 33.99m-p 37.66 i-m 41.87 d-i 35.11 FG

CaCO3200 ppm 36.33 f-j 40.17 b-f 48.17 a 42.83 bc $\mathbf{4 1 . 8 8}$ A 36.52 k-n 40.07 f-l 51.18 a 43.98 c-h 42.94 A

CaCO3300 ppm 31.00 l-o 37.33 d-h 43.00 bc 39.93 c-f 37.82 CD 32.17 n-p 37.50 i-m 45.65 b-d 39.86 f-1 38.80 CD

Kaolin 1\% 26.83 op 30.83m-p 33.17 h-n 40.50 b-f 32.83 FG 27.38 qr 30.82 p-r 36.28 k-o 44.03 c-g 34.63 FG

Kaolin 2\% $\quad 31.33$ l-n 38.13 d-g 44.33 ab 40.17 b-f 38.49 BC 31.11 p-r 36.76 j-m 49.04 ab 41.98 d-i 39.72 BC

Kaolin 3\% 30.17m-p 42.67 bc 36.83 e-i 34.00g-m 35.92 DE 29.44 p-r 44.72 b-e 39.48 g-1 36.06 k-o 37.42 DE

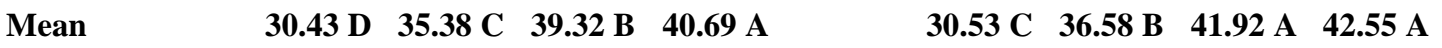

Means having the same letter within a column or rows are not significantly differed at 0.05 level of probability according to Duncan's multiple range test. 


\section{Umbrella width (cm)}

For atheistic values umbrella width was measured. Irrigating plants at $100 \%$ WHC recorded the highest values for umbrella width in both seasons (40.96 and $42.55 \mathrm{~cm}$, in the first and second seasons, respectively). This influence was significant when compared with other irrigating levels in the first season, while in the second one there was no significant difference between irrigating at $100 \%$ WHC and 75\% WHC which recorded $41.92 \mathrm{~cm}$ (Table 4).

Both $\mathrm{CaCO}_{3}$ at 200 ppm and active dry yeast extract at $3 \%$ gave the highest significant values of umbrella width (41.88 and 42.94 for $\mathrm{CaCO}_{3}$ and 39.96 and $41.95 \mathrm{~cm}$ for active dry yeast in both seasons, respectively).

Irrigating at $75 \% \mathrm{WHC}$ in addition to spraying with $\mathrm{CaCO}_{3}$ at $200 \mathrm{ppm}$ recorded the widest umbrella in both seasons as recorded 48.17 and $51.18 \mathrm{~cm}$, respectively. Such treatment did not significantly differ than some other combined treatments i.e.; kaolin at $2 \%+\mathrm{WHC}$ at $75 \%$, active dry yeast at $2 \%+\mathrm{WHC}$ at $100 \%$ and active dry yeast at $3 \%+\mathrm{WHC}$ at $100 \%$ as illustrated in Table 4.

\section{Vegetative growth fresh weight (g)}

As it shown in Table 5, there was a great superiority to irrigating cyperus plants at $100 \%$ WHC as it resulted in the highest significant vegetative growth fresh weight in both seasons (64.76 and $68.83 \mathrm{~g}$ in both seasons, respectively). This was followed by irrigating at $75 \%$ WHC in both seasons (62.89 and $67.28 \mathrm{~g}$, respectively), with significant difference between them in both seasons. On the other hand, the lowest values were obtained by irrigating at $25 \% \mathrm{WHC}$ as recorded 45.28 and $46.25 \mathrm{~g}$ in both seasons, respectively.

It could be noticed that spraying with active dry yeast extract at 3\% significantly increased vegetative growth fresh weight to the highest values in both seasons (66.60 and $70.74 \mathrm{~g}$, respectively). While, spraying with $\mathrm{CaCO}_{3}$ at $200 \mathrm{ppm}$ occupied the second position (63.99 and $68.23 \mathrm{~g}$, respectively).

Both combined treatments between irrigating at $100 \%$ WHC in addition to spraying with active dry yeast extract at $3 \%$ and irrigating at $75 \%$ WHC in addition to spraying with $\mathrm{CaCO}_{3}$ at 200 ppm produced the heaviest vegetative growth fresh weights in both seasons without significant differences between them $(80.88$ and $89.91 \mathrm{~g}$ in case of the first treatment and 78.25 and 86.83 in case of the second one, in both seasons, respectively). On the other hand, all combined treatments comprising irrigating at $25 \%$ WHC produced the lowest values (Table 5).

\section{Vegetative growth dry weight $(\mathrm{g})$}

Irrigating cyperus plants at $100 \%$ WHC resulted in the highest significant vegetative growth dry weight in both seasons (15.77 and $16.82 \mathrm{~g}$ in both seasons, respectively). This was followed by irrigating at 75\% WHC in both seasons (15.09 and $16.10 \mathrm{~g}$, respectively), with significant difference between them in both seasons. On the other hand, the lowest values were obtained by irrigating at $25 \%$ WHC as recorded 9.87 and $9.32 \mathrm{~g}$ in both seasons, respectively (Table 5).

It could be noticed that spraying with active dry yeast extract at $3 \%$ significantly increased vegetative growth dry weight to the highest values in both seasons (15.68 and $16.79 \mathrm{~g}$, respectively). This was followed by spraying with $\mathrm{CaCO}_{3}$ at 200 ppm without significant difference in the first season $(15.13 \mathrm{~g})$ and with significant difference in the second one $(15.64 \mathrm{~g})$.

Both combined treatments between irrigating at $100 \%$ WHC in addition to spraying with active dry yeast extract at $3 \%$ and irrigating at $75 \%$ WHC in addition to spraying with $\mathrm{CaCO}_{3}$ at $200 \mathrm{ppm}$ produced the heaviest vegetative growth dry weights in both seasons. The differences between both combined treatments were insignificant in the first season (21.13 and $20.42 \mathrm{~g}$, respectively), while, in the second one there were a significant difference between them (23.96 and $21.19 \mathrm{~g}$, for the first and second combined treatments, respectively). On the other hand, all combined treatments comprising irrigating at $25 \%$ WHC produced the lowest values (Table 5).

\section{Underground part growth parameters}

\section{Root length (cm)}

Data in Table 6 indicate that, irrigating cyperus plants at $100 \%$ WHC resulted in the longest roots ( 85.72 and $90.68 \mathrm{~cm}$, in the first and second seasons, respectively). This was followed by irrigating at $75 \%$ WHC in both seasons $(81.26$ and $86.08 \mathrm{~cm}$, respectively), with significant difference between them in both seasons. On the other hand, the lowest values were obtained by irrigating at $25 \% \mathrm{WHC}$ as recorded 57.20 and $58.06 \mathrm{~cm}$ in both seasons, respectively.

It could be noticed that spraying with either kaolin at $2 \%$ or $\mathrm{CaCO}_{3}$ at $200 \mathrm{ppm}$ significantly increased root length to the highest values in the first season (91.83 and $89.44 \mathrm{~cm}$, respectively). While, in the second season the mastery was to spraying with $\mathrm{CaCO}_{3}$ at $200 \mathrm{ppm}(96.96 \mathrm{~cm})$. 
Table 5. Effect of water irrigation level, anti-transpirant type and concentration and their interactions on vegetative growth fresh and dry weights (g) of Cyperus alternifolius L. plants during 2015/2016 and 2016/2017 seasons

\begin{tabular}{|c|c|c|c|c|c|c|c|c|c|}
\hline \multirow{4}{*}{$\begin{array}{l}\text { Irrigation } \\
\text { level } \\
\text { Anti- } \\
\text { transpirants }\end{array}$} & \multicolumn{4}{|c|}{ First season } & \multicolumn{5}{|c|}{ Second season } \\
\hline & \multicolumn{9}{|c|}{ Vegetative growth fresh weight (g) } \\
\hline & \multicolumn{3}{|c|}{ WHC (\%) } & \multirow{2}{*}{ Mean } & \multicolumn{4}{|c|}{ WHC (\%) } & \multirow{2}{*}{ Mean } \\
\hline & 25 & $\begin{array}{ll}50 & 75 \\
\end{array}$ & 100 & & 25 & 50 & 75 & 100 & \\
\hline Control & $36.23 \mathrm{wx}$ & $53.55 \mathrm{~m}-\mathrm{p} 56.66 \mathrm{j}-\mathrm{m}$ & $65.46 \mathrm{~d}-\mathrm{f}$ & & 38.11 o & $50.81 \mathrm{~lm}$ & $59.79 \mathrm{~h}-\mathrm{j}$ & $64.59 \mathrm{fg}$ & \\
\hline ADY $1 \%$ & $46.80 \mathrm{~s}-\mathrm{u}$ & $53.55 \mathrm{~m}-\mathrm{p} 60.16 \mathrm{~g}-\mathrm{k}$ & $69.49 \mathrm{~b}-\mathrm{d}$ & $\mathbf{5 7 . 5 0} \mathbf{E}$ & $44.77 \mathrm{n}$ & $53.53 \mathrm{kl}$ & $60.91 \mathrm{~g}-\mathrm{i}$ & $73.72 \mathrm{~cd}$ & \\
\hline ADY & $50.60 \mathrm{o}-\mathrm{t}$ & $55.72 \mathrm{k}-\mathrm{n} 64.47 \mathrm{e}-\mathrm{g}$ & $72.87 \mathrm{~b}$ & $60.91 \mathrm{C}$ & $50.95 \mathrm{~lm}$ & $56.38 \mathrm{jk}$ & $65.05 \mathrm{fg}$ & $79.92 \mathrm{~b}$ & 63.08 C \\
\hline ADY 3\% & $55.031-0$ & $60.93 \mathrm{~g}-\mathrm{j} 69.58 \mathrm{~b}-\mathrm{d}$ & $80.88 \mathrm{a}$ & $66.60 \mathrm{~A}$ & $57.42 \mathrm{i}-\mathrm{k}$ & $63.37 \mathrm{f}-\mathrm{h}$ & $72.26 \mathrm{~d}$ & $89.91 \mathrm{a}$ & \\
\hline $\mathrm{CaCO}_{3} 100$ ppm & $37.25 \mathrm{wx}$ & $48.03 \mathrm{r}-\mathrm{u} 59.30 \mathrm{~h}-1$ & & & $38.41 \mathrm{o}$ & $48.61 \mathrm{mn}$ & $61.23 \mathrm{~g}-\mathrm{i}$ & $67.04 \mathrm{ef}$ & \\
\hline $\mathrm{CaCO}_{3} 200$ ppm & $53.00 \mathrm{~m}-\mathrm{q}$ & $57.21 \mathrm{i}-\mathrm{m} 78.25 \mathrm{a}$ & $67.51 \mathrm{c}-\mathrm{e}$ & $63.99 \mathrm{~B}$ & $53.70 \mathrm{kl}$ & $61.23 \mathrm{~g}-\mathrm{i}$ & $86.83 \mathrm{a}$ & $71.15 \mathrm{de}$ & 3 B \\
\hline $\mathrm{CaCO}_{3} 300$ ppm & $44.13 \mathrm{uv}$ & $55.68 \mathrm{k}-\mathrm{n} 70.52 \mathrm{bc}$ & $62.65 \mathrm{f}-1$ & $58.24 \mathrm{DE}$ & $44.62 n$ & $55.81 \mathrm{jk}$ & $80.03 \mathrm{~b}$ & $63.70 \mathrm{f}-\mathrm{h}$ & $61.04 \mathrm{C}$ \\
\hline Kaolin 1\% & $37.37 \mathrm{wx}$ & $46.22 \mathrm{tu} 49.06 \mathrm{p}-\mathrm{t}$ & $53.74 \mathrm{~m}$ & $46.60 \mathrm{H}$ & 38.87 o & $50.20 \mathrm{~lm}$ & $54.08 \mathrm{kl}$ & 59.85 h-j & 50.75 F \\
\hline n $2 \%$ & $52.03 \mathrm{n}-\mathrm{r}$ & $57.50 \mathrm{i}-\mathrm{m} 69.64 \mathrm{~b}$ & 62.56 & & $50.66 \mathrm{~lm}$ & $58.42 \mathrm{ij}$ & $76.50 \mathrm{bc}$ & $64.93 \mathrm{fg}$ & $3 \mathrm{C}$ \\
\hline Kaolin 3 & $40.34 \mathrm{vw}$ & $61.71 \mathrm{f}-\mathrm{i} 51.22 \mathrm{n}-\mathrm{s}$ & & & $45.01 \mathrm{n}$ & $66.37 \mathrm{f}$ & $56.16 \mathrm{jk}$ & $53.53 \mathrm{kl}$ & \\
\hline \multirow[t]{2}{*}{ Mean } & & $55.01 \mathrm{C} \quad 62.89 \mathrm{~B}$ & $64.76 \mathrm{~A}$ & & 46.25 D & $56.47 \mathrm{C}$ & $67.28 \mathrm{~B}$ & $68.83 \mathrm{~A}$ & \\
\hline & \multicolumn{9}{|c|}{ Vegetative growth dry weight (g) } \\
\hline Cont & & 10.33 no $12.89 \mathrm{~h}-\mathrm{j}$ & $15.48 \mathrm{de}$ & & $7.61 \mathrm{tu}$ & $10.93 \mathrm{n}-\mathrm{s}$ & & & \\
\hline ADY $1 \%$ & $2 \mathrm{qr}$ & 10.89 l-o $14.13 \mathrm{f}-\mathrm{h}$ & $16.46 \mathrm{~cd}$ & 12.30EF & $7.62 \mathrm{tu}$ & $11.21 \mathrm{n}-\mathrm{r}$ & $15.21 \mathrm{hi}$ & 18.4 & DE \\
\hline ADY $2 \%$ & 10.20 no & 13.08 hi $14.69 \mathrm{e}-\mathrm{g}$ & $18.81 \mathrm{~b}$ & 14.19C & $9.92 \mathrm{q}-\mathrm{s}$ & $12.59 \mathrm{j}-\mathrm{n}$ & $16.43 \mathrm{gh}$ & $19.95 \mathrm{~b}-\mathrm{d}$ & $14.72 \mathrm{C}$ \\
\hline ADY 3\% & $12.17 \mathrm{i}-1$ & $13.59 \mathrm{gh} 15.83 \mathrm{de}$ & $21.13 \mathrm{a}$ & $15.68 \mathrm{~A}$ & $11.77 \mathrm{~m}-\mathrm{p}$ & $14.30 \mathrm{ij}$ & $17.13 \mathrm{e}-\mathrm{g}$ & $23.96 \mathrm{a}$ & 16.79 A \\
\hline $\mathrm{CaCO}_{3} 100$ ppm & $8.80 \mathrm{p}$ & $10.82 \mathrm{~m}-\mathrm{o} \quad 12.13 \mathrm{i}-1$ & $15.93 \mathrm{c}-\mathrm{e}$ & $11.92 G$ & $6.87 \mathrm{u}$ & $10.43 \mathrm{o}-\mathrm{s}$ & $13.69 \mathrm{i}-1$ & $16.71 \mathrm{f}-\mathrm{h}$ & $11.93 \mathrm{~F}$ \\
\hline $\mathrm{CaCO}_{3} 200$ ppm & $11.17 \mathrm{k}-\mathrm{n}$ & $13.23 \mathrm{hi} \quad 20.42 \mathrm{a}$ & $15.69 \mathrm{de}$ & 15.13AB & $11.13 \mathrm{n}-\mathrm{r}$ & $13.79 \mathrm{i}-1$ & $21.19 \mathrm{~b}$ & $16.43 \mathrm{gh}$ & 15.64 B \\
\hline $\mathrm{CaCO}_{3} 300$ ppm & 9.61 op & $12.26 \mathrm{i}-\mathrm{k} \quad 17.16 \mathrm{c}$ & $14.17 \mathrm{f}-\mathrm{h}$ & 13.30D & $9.84 \mathrm{rs}$ & $12.35 \mathrm{k}-\mathrm{n}$ & $18.39 \mathrm{~d}-\mathrm{f}$ & 15.1 & CD \\
\hline Kaolin 1\% & $8.86 \mathrm{p}$ & 9.99 no $11.77 \mathrm{j}-\mathrm{m}$ & $13.29 \mathrm{hi}$ & $10.98 H$ & $7.32 \mathrm{u}$ & $10.20 \mathrm{p}-\mathrm{s}$ & $12.041-\mathrm{o}$ & $13.24 \mathrm{j}-\mathrm{m}$ & \\
\hline Kaolin 2\% & $12.02 \mathrm{i}-\mathrm{m}$ & $13.85 \mathrm{f}-\mathrm{h} \quad 18.78 \mathrm{~b}$ & $15.01 \mathrm{ef}$ & $14.91 B$ & $11.92 \mathrm{~m}-\mathrm{p}$ & $14.27 \mathrm{ij}$ & $20.14 \mathrm{bc}$ & $16.09 \mathrm{gh}$ & $15.60 \mathrm{~B}$ \\
\hline Kaolin 3\% & 9.66 op & $15.59 \mathrm{de} \quad 13.12 \mathrm{hi}$ & $11.75 \mathrm{j}-\mathrm{m}$ & $12.53 \mathrm{E}$ & $9.22 \mathrm{st}$ & $16.78 \mathrm{e}-\mathrm{h}$ & $13.83 \mathrm{i}-\mathrm{k}$ & $11.60 \mathrm{~m}-\mathrm{q}$ & $12.86 \mathrm{E}$ \\
\hline Mean & $9.87 \mathrm{D}$ & $12.36 \mathrm{C} \quad 15.09 \mathrm{~B}$ & $15.77 \mathrm{~A}$ & & $9.32 \mathrm{C}$ & $12.69 \mathrm{C}$ & $16.10 \mathrm{~B}$ & $16.82 \mathrm{~A}$ & \\
\hline
\end{tabular}

Means having the same letter within a column or rows are not significantly differed at 0.05 level of probability according to Duncan's multiple range test.

Irrigating at $100 \% \mathrm{WHC}$ in addition to spraying with active dry yeast extract at $3 \%$ produced the longest root length in both seasons (112.00 and $118.20 \mathrm{~cm}$, respectively). Irrigating at $75 \%$ of WHC in addition to spraying with $\mathrm{CaCO}_{3}$ at $200 \mathrm{ppm}$ significantly came in the second position in the first season $(105.20 \mathrm{~cm})$, while in the second season there was no significant difference between this combined treatment (as recorded $111.60 \mathrm{~cm}$ ) and the abovementioned treatment. On the other hand, all combined treatments comprising irrigating at $25 \%$ WHC produced the lowest values (Table 6).

\section{Number of offsets/plant}

Irrigating cyperus plants at $100 \%$ WHC resulted in the highest significant values in terms of number of offsets/plant (2.33 and 2.50, in the first and second seasons respectively). This was followed by irrigating at $75 \%$ WHC in both seasons (1.93 and 2.17, respectively), with significant difference between them in both seasons. On the other hand, the lowest values were obtained by irrigating at $25 \%$ WHC as recorded 1.10 and 1.07 in both seasons, respectively (Table 6).

Active dry yeast extract at $3 \%$ was the most effective treatment in this regard as resulted the highest values of number of offsets/plant (2.67 for each season). Spraying with $\mathrm{CaCO}_{3}$ at 200 ppm occupied the second position in both seasons as recorded 2.00 and 2.19, respectively.

Irrigating at $100 \% \mathrm{WHC}$ in addition to spraying with active dry yeast extract at $3 \%$ produced the highest number of offsets/plant in both seasons (4.00 and 4.1, respectively). In this regard, irrigating at $75 \%$ WHC in addition to spraying with $\mathrm{CaCO}_{3}$ at $200 \mathrm{ppm}$ occupied the second position in both seasons as recorded 3.33 and 3.92, respectively. On the other hand all combinations included irrigating at $25 \%$ WHC resulted in the lowest values (Table 6). 
Table 6. Effect of water irrigation level, anti-transpirants type and concentration and their interactions on root length (cm), number of offsets/plant of Cyperus alternifolius L. plants during 2015/2016 and 2016/2017 seasons

\begin{tabular}{|c|c|c|c|c|c|c|c|c|c|c|}
\hline \multirow{4}{*}{$\begin{array}{l}\text { Anti- } \\
\text { transpirants }\end{array}$} & \multicolumn{5}{|c|}{ First season } & \multicolumn{5}{|c|}{ Second season } \\
\hline & \multicolumn{10}{|c|}{ Root length (cm) } \\
\hline & \multicolumn{4}{|c|}{ WHC (\%) } & \multirow{2}{*}{ Mean } & \multicolumn{4}{|c|}{ WHC (\%) } & \multirow{2}{*}{ Mean } \\
\hline & 25 & 50 & 75 & 100 & & 25 & 50 & 75 & 100 & \\
\hline Control & $42.09 \mathrm{v}$ & $50.38 \mathrm{tu}$ & $62.50 \mathrm{o}$ & $68.671-0$ & 55.91 F & $40.86 \mathrm{w}$ & $58.32 \mathrm{r}-\mathrm{t}$ & $72.04 \mathrm{nc}$ & $81.36 \mathrm{j}-\mathrm{m}$ & $4 \mathrm{G}$ \\
\hline DY $1 \%$ & $42.17 \mathrm{v}$ & $55.19 \mathrm{st}$ & $67.88 m-p$ & $79.50 \mathrm{~g}-\mathrm{j}$ & $61.18 \mathrm{E}$ & $43.52 \mathrm{x}$ & $57.18 \mathrm{~s}-\mathrm{u}$ & $70.17 \mathrm{n}-\mathrm{p}$ & $85.98 \mathrm{~g}-\mathrm{k}$ & $1 \mathrm{G}$ \\
\hline ADY $2 \%$ & $45.83 \mathrm{uv}$ & $59.67 \mathrm{q}-\mathrm{s}$ & $77.00 \mathrm{~h}-\mathrm{k}$ & $87.83 \mathrm{~d}-\mathrm{f}$ & $67.58 \mathrm{D}$ & $44.51 \mathrm{vw}$ & $66.43 \mathrm{o}-\mathrm{q}$ & 82.96 h-1 & & $71.93 \mathrm{E}$ \\
\hline DY 3\% & $56.25 \mathrm{r}-\mathrm{t}$ & $68.17 \mathrm{~m}-\mathrm{o}$ & $80.00 \mathrm{~g}-\mathrm{i}$ & 112.00 & 79.10 BC & $55.63 \mathrm{tu}$ & $74.78 \mathrm{mn}$ & $e-i$ & $18.20 \mathrm{a}$ & $2 \mathrm{C}$ \\
\hline $\mathrm{CaCO}_{3} 100$ ppm & $48.58 \mathrm{uv}$ & 60.75 q-s & $73.08 \mathrm{j}-1$ & $85.83 \mathrm{e}$ & 67.06 D & $50.65 \mathrm{uv}$ & $64.85 \mathrm{p}-\mathrm{r}$ & 250 & c-e & $\mathbf{E F}$ \\
\hline $\mathrm{CaCO}_{3} 200$ ppm & $72.83 \mathrm{k}-\mathrm{m}$ & $85.83 \mathrm{e}-\mathrm{g}$ & $105.20 \mathrm{~b}$ & $93.92 \mathrm{~cd}$ & 89.44 A & 85.53 h-k & . & 1.00 & & $96.96 \mathrm{~A}$ \\
\hline $\mathrm{CaCO}_{3} 300$ ppm & $61.50 \mathrm{p}-\mathrm{s}$ & $75.86 \mathrm{~h}-\mathrm{k}$ & $98.67 \mathrm{bc}$ & $89.67 \mathrm{de}$ & 81.42 B & $62.80 \mathrm{q}-\mathrm{s}$ & $79.66 \mathrm{k}-\mathrm{m}$ & $102.00 \mathrm{c}$ & $88.14 \mathrm{f}-\mathrm{j}$ & 83.14 C \\
\hline Kaolin 1\% & $55.50 \mathrm{st}$ & $59.67 \mathrm{q}-\mathrm{s}$ & $69.111-n$ & $74.83 \mathrm{i}-1$ & $64.78 \mathrm{D}$ & $56.92 \mathrm{~s}-\mathrm{u}$ & $00.50-4$ & 10 & & \\
\hline Kaolin 2\% & $82.33 \mathrm{f}-\mathrm{h}$ & $89.67 \mathrm{de}$ & $102.00 \mathrm{~b}$ & $93.33 \mathrm{~cd}$ & $91.83 \mathrm{~A}$ & $82.07 \mathrm{i}-1$ & 84.72 h-k & $0.40 \mathrm{~b}$ & 89.17 e-h & $91.60 \mathrm{~B}$ \\
\hline Kaolin 3\% & $64.92 \mathrm{n}-\mathrm{q}$ & $91.33 \mathrm{de}$ & $77.17 \mathrm{~h}-\mathrm{k}^{\prime}$ & $71.58 \mathrm{k}-\mathrm{m}$ & & $63.53 \mathrm{p}-\mathrm{s}$ & $92.66 \mathrm{~d}-\mathrm{g}$ & & $1-n$ & \\
\hline \multirow[t]{2}{*}{ Mean } & & $69.65 \mathrm{C}$ & 81.26 B & $85.72 \mathrm{~A}$ & & $58.60 \mathrm{D}$ & 73.77 C & 86.08 B & $90.68 \mathrm{~A}$ & \\
\hline & \multicolumn{10}{|c|}{ Number of offsets/plant } \\
\hline Control & & $1.00 \mathrm{~h}$ & $1.67 \mathrm{fg}$ & $2.33 \mathrm{de}$ & $1.50 \mathrm{D}-\mathrm{F}$ & $1.00 \mathrm{o}$ & $1.10 \mathrm{~m}-\mathrm{o}$ & $1.85 \mathrm{~h}-1$ & $2.61 \mathrm{de}$ & \\
\hline ADY $1 \%$ & $1.00 \mathrm{~h}$ & $1.00 \mathrm{~h}$ & $1.33 \mathrm{gh}$ & $2.33 \mathrm{de}$ & $1.42 \mathrm{EF}$ & $1.00 \mathrm{o}$ & $1.09 \mathrm{no}$ & $1.72 \mathrm{i}-1$ & $2.65 \mathrm{~d}$ & $1.62 \mathrm{DE}$ \\
\hline ADY $2 \%$ & $1.00 \mathrm{~h}$ & $1.33 \mathrm{gh}$ & $2.00 \mathrm{ef}$ & $3.00 \mathrm{bc}$ & $1.83 \mathrm{BC}$ & $1.02 \mathrm{o}$ & $1.381-\mathrm{o}$ & $2.17 \mathrm{~d}-\mathrm{j}$ & $3.40 \mathrm{bc}$ & $1.99 \mathrm{BC}$ \\
\hline ADY 3\% & $2.00 \mathrm{ef}$ & $2.33 \mathrm{de}$ & $2.33 \mathrm{de}$ & $4.00 \mathrm{a}$ & $2.67 \mathrm{~A}$ & $1.65 \mathrm{j}-\mathrm{m}$ & $2.11 \mathrm{~d}-\mathrm{k}$ & $2.52 \mathrm{~d}-\mathrm{f}$ & $4.41 \mathrm{a}$ & $2.67 \mathrm{~A}$ \\
\hline $\mathrm{CaCO}_{3} 100$ ppm & $1.00 \mathrm{~h}$ & $1.00 \mathrm{~h}$ & $1.00 \mathrm{~h}$ & $2.67 \mathrm{~cd}$ & $1.42 \mathrm{EF}$ & $1.00 \mathrm{o}$ & 1.05 no & $1.15 \mathrm{~m}-\mathrm{o}$ & $2.64 \mathrm{~d}$ & $1.46 \mathrm{EF}$ \\
\hline $\mathrm{CaCO}_{3} 200$ ppm & $1.00 \mathrm{~h}$ & $1.67 \mathrm{fg}$ & $3.33 \mathrm{~b}$ & $2.00 \mathrm{ef}$ & $2.00 \mathrm{~B}$ & $1.01 \mathrm{o}$ & $1.60 \mathrm{k}-\mathrm{n}$ & $3.92 \mathrm{ab}$ & $2.23 \mathrm{~d}-\mathrm{i}$ & 2.19 B \\
\hline $\mathrm{CaCO}_{3} 300$ ppm & $1.00 \mathrm{~h}$ & $1.00 \mathrm{~h}$ & $3.00 \mathrm{bc}$ & $2.00 \mathrm{ef}$ & 1.75 B-D & $1.00 \mathrm{o}$ & $1.11 \mathrm{~m}-\mathrm{o}$ & $3.28 \mathrm{c}$ & $1.93 \mathrm{~g}-1$ & $1.83 \mathrm{CD}$ \\
\hline Kaolin 1\% & $1.00 \mathrm{~h}$ & $1.00 \mathrm{~h}$ & $1.00 \mathrm{~h}$ & $2.00 \mathrm{ef}$ & $1.25 \mathrm{~F}$ & $1.00 \mathrm{o}$ & $1.00 \mathrm{o}$ & $1.16 \mathrm{~m}-\mathrm{o}$ & $2.06 \mathrm{e}-\mathrm{k}$ & $1.31 \mathrm{~F}$ \\
\hline Kaolin 2\% & $1.00 \mathrm{~h}$ & $1.00 \mathrm{~h}$ & $2.33 \mathrm{de}$ & $2.00 \mathrm{ef}$ & $1.58 \mathrm{C}-\mathrm{E}$ & $1.02 \mathrm{o}$ & $1.16 \mathrm{~m}-\mathrm{o}$ & $2.47 \mathrm{~d}-\mathrm{g}$ & $2.03 \mathrm{f}-\mathrm{k}$ & $1.67 \mathrm{DE}$ \\
\hline Kaolin 3\% & $1.00 \mathrm{~h}$ & $2.00 \mathrm{ef}$ & $1.33 \mathrm{gh}$ & $1.00 \mathrm{~h}$ & $1.33 \mathrm{EF}$ & $1.00 \mathrm{o}$ & $2.29 \mathrm{~d}-\mathrm{h}$ & $1.43 \mathrm{l}-\mathrm{o}$ & 1.06 no & $1.45 \mathrm{EF}$ \\
\hline Mean & $1.10 \mathrm{D}$ & $1.33 \mathrm{C}$ & $1.93 \mathrm{~B}$ & $2.33 \mathrm{~A}$ & & $1.07 \mathrm{D}$ & $1.39 \mathrm{C}$ & $2.17 \mathrm{~B}$ & $2.50 \mathrm{~A}$ & \\
\hline
\end{tabular}

Means having the same letter within a column or rows are not significantly differed at 0.05 level of probability according to Duncan's multiple range test.

\section{Roots fresh weight (g)}

Irrigating cyperus plants at either $75 \%$ or $100 \%$ WHC resulted in the highest significant roots fresh weight $(84.43$ and $87.54 \mathrm{~g}$ for the first treatment and 83.65 and $87.46 \mathrm{~g}$ for the second one in the first and second seasons, respectively). On the other hand, the lowest values were obtained by irrigating at $25 \%$ WHC as recorded 39.97 and 40.91 in both seasons, respectively (Table 7).

It could be noticed that spraying with active dry yeast extract at $3 \%$ produced the highest significant values of roots fresh weight in both seasons as recorded 97.27 and $103.70 \mathrm{~g}$ respectively. In this regard, spraying with $\mathrm{CaCO}_{3}$ at 200 ppm occupied the second position as recorded 81.94 and $84.08 \mathrm{~g}$ in both seasons, respectively.
Irrigating at $100 \% \mathrm{WHC}$ in addition to spraying with active dry yeast extract at $3 \%$ significantly produced the highest roots fresh weight in both seasons (135.30 and $144.10 \mathrm{~g}$, respectively). Irrigating at $75 \%$ of $\mathrm{WHC}$ in addition to spraying with $\mathrm{CaCO}_{3}$ at 200 ppm came in the second position in both seasons (123.00 and $129.60 \mathrm{~g}$, in the first and second seasons, respectively). On the other hand, all combined treatments comprising irrigating at $25 \%$ WHC produced the lowest values (Table 7).

\section{Roots dry weight (g)}

Irrigating cyperus plants at either $75 \%$ or $100 \%$ WHC resulted in the highest significant roots dry weight in both seasons (35.94 and $38.20 \mathrm{~g}$ for $75 \%$ WHC and 35.16 and $37.59 \mathrm{~g}$ for $100 \%$ WHC in the first and second seasons, respectively). On the other 
hand, the lowest values were obtained by irrigating at $25 \%$ WHC as recorded 14.69 and $15.30 \mathrm{~g}$ in both seasons, respectively (Table 7).

Spraying with active dry yeast extract at $3 \%$ or kaolin at $2 \%$ significantly increased roots dry weight to the highest values in both seasons (37.59 and $39.85 \mathrm{~g}$ for active dry yeast extract at $3 \%$ and 35.92 and $38.37 \mathrm{~g}$ for kaolin at $2 \%$ in the first and second seasons, respectively) without significant differences between them. This was followed by spraying with $\mathrm{CaCO}_{3}$ at 200 ppm (31.48 and $33.48 \mathrm{~g}$ in both seasons, respectively).
Both combined treatments between irrigating at $100 \%$ WHC in addition to spraying with active dry yeast extract at $3 \%$ and irrigating at $75 \%$ WHC in addition to spraying with $\mathrm{CaCO}_{3}$ at $200 \mathrm{ppm}$ produced the heaviest roots dry weight in both seasons (59.69 and $63.40 \mathrm{~g}$ for the first combined treatment and 56.12 and $61.08 \mathrm{~g}$ for the second combined treatment in the first and second seasons, respectively) without significant differences between them. On the other hand, all combined treatments comprising irrigating at $25 \%$ WHC produced the lowest values (Table 7).

Table 7. Effect of water irrigation level, anti-transpirants type and concentration and their interactions on underground parts fresh and dry weights (g) of Cyperus alternifolius, L. plants during 2015/2016 and 2016/2017 seasons

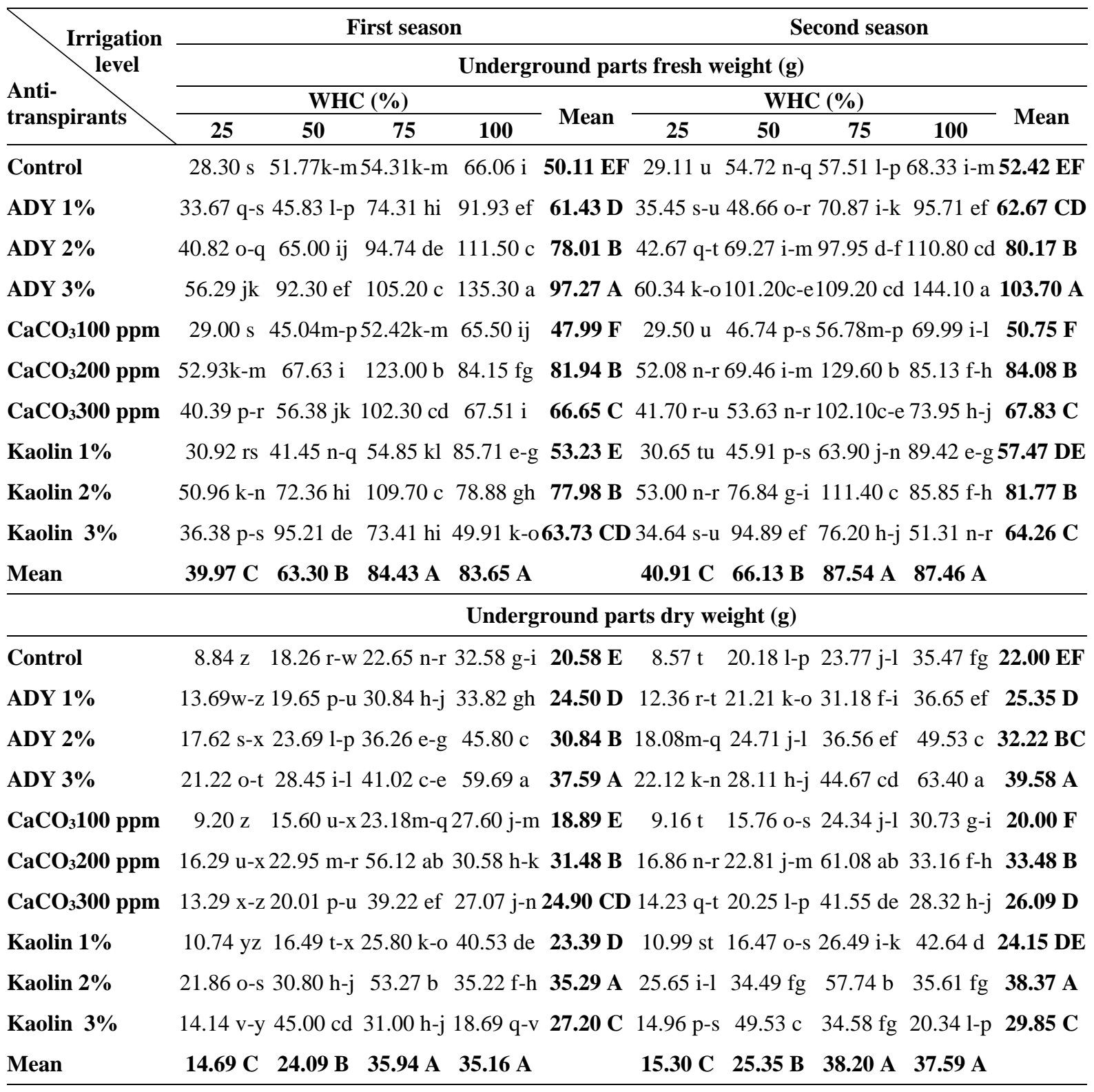

Means having the same letter within a column or rows are not significantly differed at 0.05 level of probability according to Duncan's multiple range test. 


\section{Chemical constituents}

\section{Pigments content in the leaves (mg/g f.w.)}

Data in Table 8 indicate that, irrigating cyperus plants at $75 \%$ led to increase chlorophyll a, b and carotenoids in the leaves to the highest values (0.626, 0.325 and $0.085 \mathrm{mg} / \mathrm{g}$ f.w., respectively). This increment was significant in case of chlorophyll b only. While, in case of chlorophyll a, irrigating at $100 \%$ WHC shared the previous mentioned treatment the same order and gave $0.622 \mathrm{mg} / \mathrm{g}$ f.w. without significant differences. In this regard, irrigating at $50 \%$ WHC give the same value of carotenoids that obtained by irrigating at $75 \%$ WHC (0.085 mg/g f.w.).

It could be observed that spraying cyperus plants with $\mathrm{CaCO}_{3}$ at 200 ppm produced the highest significant values regarding chlorophyll a, b and carotenoids as recorded $0.879,0.491$ and $0.112 \mathrm{mg} / \mathrm{g}$ f.w., respectively.

Irrigating cyperus plants at $75 \% \mathrm{WHC}$ in addition to spraying with $\mathrm{CaCO}_{3}$ at 200 ppm resulted in the highest pigments content as recorded 0.897, 0.542 and $0.119 \mathrm{mg} / \mathrm{g}$ f.w. for chlorophyll $\mathrm{a}, \mathrm{b}$ and carotenoids, respectively. This increment was significant in case of chlorophyll b only. While, in case of chlorophyll a and carotenoids many other combined treatments shared this treatment the same order i.e.; irrigating at $100 \%$ WHC in addition spraying with $\mathrm{CaCO}_{3}$ at 200 ppm in case of chlorophyll a $(0.885 \mathrm{mg} / \mathrm{g}$ f.w.) and irrigating at $50 \%$ WHC in addition to spraying with $\mathrm{CaCO}_{3}$ at $200 \mathrm{ppm}$ in case of carotenoids $(0.115 \mathrm{mg} / \mathrm{g}$ f.w.). These results are shown in Table 8 .

\section{Total carbohydrates percentage}

Irrigating cyperus plants at either $75 \%$ or $100 \%$ WHC resulted in the highest significant value of total carbohydrates percentage as recorded 25.150 and $25.080 \%$, respectively. On the other hand, the lowest values were obtained by irrigating at $25 \%$ WHC as recorded $23.470 \%$ (Table 9).

Spraying with $\mathrm{CaCO}_{3}$ at 200 ppm was superior in increasing total carbohydrates percentage as recorded $34.350 \%$. While, control treatment (without spraying) produced the lowest significant percentage $(12.190 \%)$.

The highest significant total carbohydrates percentage $(37.060 \%)$ was obtained by irrigating at $75 \%$ WHC in addition to spraying with $\mathrm{CaCO}_{3}$ at $200 \mathrm{ppm}$. On the other hand, the lowest total carbohydrates were obtained with control treatment (Table 9).

\section{Proline content (mg/g d.w.)}

It is clear that the highest significant proline content was obtained as a result to irrigate the plants with the lowest irrigation level (25\% of WHC) when compared with other levels as recorded $(0.517 \mathrm{~g} / \mathrm{g}$ d.w.). The ore the irrigation level was increased, the less proline content was obtained (Table 9).

The highest significant proline content $(0.506$ $\mathrm{mg} / \mathrm{g}$ d.w.) was obtained when plants did not concomitant with spray with any anti-transpirants or sprayed with active dry yeast extract at $1 \%(0.505$ mg/ g d.w.). While, spraying with $\mathrm{CaCO}_{3}$ at 200 ppm reduced proline content to the lowest value (0.376 mg/g d.w.).

Irrigating at the lowest level (25\% of WHC) without any anti-transpirants led to produce the highest significant proline content $(0.605 \mathrm{mg} / \mathrm{g}$ d.w.). On the other hand, the combined treatments between irrigating at either 75 or $100 \%$ WHC in addition to spraying with $\mathrm{CaCO}_{3}$ at $200 \mathrm{ppm}$ resulted in the lowest proline contents $(0.334$ and $0.320 \mathrm{mg} / \mathrm{g}$ d.w., respectively) (Table 9).

\section{DISCUSSION}

The above-mentioned results regarding the negative effects of water deficit were in harmony with those obtained by Khalil et al. (2012) who reported that reducing irrigation water level led to reduce plant height and fresh and dry weights, this was accompanied with increasing proline content of Jatropha curcas L. Also, Noor El-Deen et al. (2018) concluded that gradually reducing irrigation water level of Zinnia elegans plants led to gradually reduce all studied trait values except for proline content which was increased. On the contrary, increasing level of water significantly increased growth and productivity of Ziziphus mauritiana (Mukherjee et al., 2004). Also, Gomaa et al. (2005) emphasized these results on cucumber.

This study emphasized that reducing water led to reduce plant growth and quality. Reducing photosynthesis by closing stomata, decreasing the efficiency of carbon fixation process, suppressing leaf formation and expansion are the common negative effects of water deficit (Pallardy, 2008). It is well known that water accounts for between $80-$ $95 \%$ of the fresh biomass of non-woody plants and plays an important role in many aspects of plant 
Table 8. Effect of water irrigation level, anti-transpirant type and concentration and their interactions on pigments content (mg/g f.w.) of Cyperus alternifolius L. plant during 2017 season

\begin{tabular}{|c|c|c|c|c|c|}
\hline \multirow{3}{*}{$\begin{array}{l}\text { Irrigation } \\
\text { level }\end{array}$} & \multicolumn{5}{|c|}{ WHC (\%) } \\
\hline & 25 & 50 & 75 & 100 & \multirow{2}{*}{ Mean } \\
\hline & \multicolumn{4}{|c|}{ Chlorophylls a (mg/g f.w.) } & \\
\hline Control & $0.235 \mathrm{t}$ & $0.237 \mathrm{t}$ & $0.237 \mathrm{t}$ & $0.238 \mathrm{t}$ & $0.237 \mathrm{~J}$ \\
\hline ADY $1 \%$ & $0.589 \mathrm{~m}$ & $0.594 \mathrm{~m}$ & 0.6531 & 0.6701 & $0.626 \mathrm{~F}$ \\
\hline ADY $2 \%$ & $0.700 \mathrm{k}$ & $0.705 \mathrm{k}$ & $0.712 \mathrm{jk}$ & $0.718 \mathrm{jk}$ & $0.709 \mathrm{E}$ \\
\hline ADY 3\% & $0.780 \mathrm{~g}-\mathrm{i}$ & $0.800 \mathrm{f}-\mathrm{h}$ & $0.801 \mathrm{f}-\mathrm{h}$ & $0.808 \mathrm{e}-\mathrm{g}$ & $0.797 \mathrm{C}$ \\
\hline $\mathrm{CaCO}_{3} 100$ ppm & $0.736 \mathrm{j}$ & $0.770 \mathrm{i}$ & $0.771 \mathrm{i}$ & $0.779 \mathrm{hi}$ & $0.764 \mathrm{D}$ \\
\hline $\mathrm{CaCO}_{3} 200$ ppm & $0.854 \mathrm{bc}$ & $0.878 \mathrm{ab}$ & $0.897 \mathrm{a}$ & $0.885 \mathrm{a}$ & 0.879 A \\
\hline $\mathrm{CaCO}_{3} 300$ ppm & $0.812 \mathrm{~d}-\mathrm{f}$ & $0.830 \mathrm{c}-\mathrm{e}$ & $0.839 \mathrm{~cd}$ & $0.838 \mathrm{~cd}$ & $0.830 \mathrm{~B}$ \\
\hline Kaolin 1\% & $0.349 \mathrm{qr}$ & $0.364 \mathrm{q}$ & $0.424 \mathrm{p}$ & $0.426 \mathrm{p}$ & $0.391 \mathrm{H}$ \\
\hline Kaolin 2\% & 0.485 o & 0.486 o & $0.581 \mathrm{~m}$ & $0.530 \mathrm{n}$ & $0.520 \mathrm{G}$ \\
\hline Kaolin 3\% & $0.311 \mathrm{~s}$ & $0.323 \mathrm{rs}$ & $0.339 \mathrm{qr}$ & $0.324 \mathrm{rs}$ & 0.324 I \\
\hline \multirow[t]{2}{*}{ Mean } & $0.585 \mathrm{C}$ & 0.599 B & 0.626 A & $0.622 \mathrm{~A}$ & \\
\hline & \multicolumn{5}{|c|}{ Chlorophylls b (mg/g f.w.) } \\
\hline Control & $0.107 \mathrm{r}$ & $0.120 \mathrm{r}$ & $0.123 \mathrm{qr}$ & $0.139 \mathrm{o}-\mathrm{q}$ & $0.122 \mathrm{H}$ \\
\hline ADY 1\% & $0.164 \mathrm{mn}$ & $0.284 \mathrm{i}$ & $0.376 \mathrm{ef}$ & $0.322 \mathrm{~h}$ & $0.287 \mathrm{E}$ \\
\hline ADY 2\% & $0.291 \mathrm{i}$ & $0.294 \mathrm{i}$ & $0.409 \mathrm{~d}$ & $0.414 \mathrm{~d}$ & $0.352 \mathrm{C}$ \\
\hline ADY 3\% & $0.343 \mathrm{~g}$ & $0.376 \mathrm{ef}$ & $0.384 \mathrm{e}$ & $0.251 \mathrm{j}$ & $0.339 \mathrm{D}$ \\
\hline $\mathrm{CaCO}_{3} 100$ ppm & $0.317 \mathrm{~h}$ & $0.382 \mathrm{e}$ & $0.360 \mathrm{f}$ & $0.339 \mathrm{~g}$ & $0.350 \mathrm{C}$ \\
\hline $\mathrm{CaCO}_{3} 200$ ppm & $0.441 \mathrm{c}$ & $0.486 b$ & $0.542 \mathrm{a}$ & $0.494 \mathrm{~b}$ & $0.491 \mathrm{~A}$ \\
\hline $\mathrm{CaCO}_{3} 300$ ppm & $0.438 \mathrm{c}$ & $0.442 \mathrm{c}$ & $0.420 \mathrm{~d}$ & $0.415 \mathrm{~d}$ & 0.429 B \\
\hline Kaolin 1\% & $0.155 \mathrm{~m}-\mathrm{o}$ & $0.168 \mathrm{~m}$ & 0.1921 & 0.149 n-p & $0.166 \mathrm{G}$ \\
\hline Kaolin 2\% & $0.209 \mathrm{k}$ & $0.220 \mathrm{k}$ & $0.287 \mathrm{i}$ & $0.299 \mathrm{i}$ & $0.254 \mathrm{~F}$ \\
\hline Kaolin 3\% & $0.137 \mathrm{pq}$ & $0.150 \mathrm{n}-\mathrm{p}$ & $0.159 \mathrm{mn}$ & $0.217 \mathrm{k}$ & 0.012 I \\
\hline \multirow[t]{2}{*}{ Mean } & $0.260 \mathrm{D}$ & $0.292 \mathrm{C}$ & 0.325 A & 0.304 B & \\
\hline & \multicolumn{5}{|c|}{ Carotenoids (mg/g f.w.) } \\
\hline Control & $0.079 \mathrm{n}-\mathrm{q}$ & $0.077 \mathrm{o}-\mathrm{s}$ & $0.076 \mathrm{p}-\mathrm{s}$ & $0.072 \mathrm{~s}$ & $0.076 \mathrm{E}$ \\
\hline ADY 1\% & $0.083 \mathrm{k}-\mathrm{n}$ & $0.089 \mathrm{ij}$ & $0.106 \mathrm{de}$ & $0.108 \mathrm{~cd}$ & 0.097 B \\
\hline ADY $2 \%$ & 0.087 i-1 & $0.091 \mathrm{hi}$ & $0.104 \mathrm{de}$ & $0.107 \mathrm{de}$ & 0.097 B \\
\hline ADY 3\% & $0.095 \mathrm{gh}$ & $0.079 \mathrm{n}-\mathrm{q}$ & $0.098 \mathrm{fg}$ & $0.096 \mathrm{gh}$ & $0.092 \mathrm{C}$ \\
\hline $\mathrm{CaCO}_{3} 100$ ppm & $0.063 \mathrm{t}$ & $0.081 \mathrm{~m}-\mathrm{p}$ & $0.103 \mathrm{~d}-\mathrm{f}$ & $0.080 \mathrm{~m}-\mathrm{p}$ & $0.082 \mathrm{D}$ \\
\hline $\mathrm{CaCO}_{3} 200$ ppm & $0.102 \mathrm{ef}$ & $0.115 \mathrm{ab}$ & $0.119 \mathrm{a}$ & $0.113 \mathrm{bc}$ & 0.112 A \\
\hline $\mathrm{CaCO}_{3} 300$ ppm & $0.057 \mathrm{u}$ & $0.085 \mathrm{j}-\mathrm{m}$ & $0.049 \mathrm{v}$ & $0.077 \mathrm{o}-\mathrm{s}$ & $0.067 \mathrm{~F}$ \\
\hline Kaolin 1\% & $0.083 \mathrm{k}-\mathrm{n}$ & $0.074 \mathrm{q}-\mathrm{s}$ & $0.051 \mathrm{v}$ & $0.038 \mathrm{w}$ & $0.062 \mathrm{G}$ \\
\hline Kaolin 2\% & $0.107 \mathrm{de}$ & $0.088 \mathrm{i}-\mathrm{k}$ & $0.062 \mathrm{tu}$ & $0.051 \mathrm{v}$ & $0.077 \mathrm{E}$ \\
\hline Kaolin 3\% & $0.078 \mathrm{n}-\mathrm{r}$ & $0.073 \mathrm{rs}$ & $0.0821-0$ & $0.043 \mathrm{w}$ & $0.069 \mathrm{~F}$ \\
\hline Mean & 0.083 B & 0.085 A & 0.085 A & $0.079 \mathrm{C}$ & \\
\hline
\end{tabular}

Means having the same letter within a column or rows are not significantly differed at 0.05 level of probability according to Duncan's multiple range test. 
Table 9. Effect of water irrigation level, anti-transpirant type and concentration and their interactions on total carbohydrates percentage and proline content (mg/g d.w.) of Cyperus alternifolius $\mathrm{L}$. plant during 2017 season

\begin{tabular}{|c|c|c|c|c|c|}
\hline \multirow{3}{*}{$\begin{array}{l}\text { Anti- } \\
\text { transpirants }\end{array}$} & \multicolumn{5}{|c|}{ WHC (\%) } \\
\hline & 25 & 50 & 75 & 100 & \multirow{2}{*}{ Mean } \\
\hline & \multicolumn{4}{|c|}{ Total carbohydrates $(\%)$} & \\
\hline \multirow[t]{2}{*}{ Control } & $9.991^{\wedge}$ & $11.410]$ & $12.420 \backslash$ & 14.920[ & $12.190 \mathrm{~J}$ \\
\hline & $20.280 \mathrm{w}$ & $20.970 \mathrm{v}$ & $21.560 \mathrm{uv}$ & $22.020 \mathrm{u}$ & $21.210 \mathrm{H}$ \\
\hline ADY $2 \%$ & $23.750 \mathrm{qr}$ & $24.190 \mathrm{q}$ & $24.870 \mathrm{p}$ & 25.130 op & $24.480 \mathrm{~F}$ \\
\hline ADY 3\% & $27.980 \mathrm{j}$ & $28.600 \mathrm{i}$ & $29.180 \mathrm{hi}$ & $29.580 \mathrm{~h}$ & 28.830 C \\
\hline $\mathrm{CaCO}_{3} 100$ ppm & $22.680 \mathrm{t}$ & $22.830 \mathrm{st}$ & $23.110 \mathrm{st}$ & $23.410 \mathrm{rs}$ & 23.010 G \\
\hline $\mathrm{CaCO}_{3} 200$ ppm & $32.340 \mathrm{~d}$ & $33.660 \mathrm{c}$ & $37.060 \mathrm{a}$ & $34.340 \mathrm{~b}$ & $34.350 \mathrm{~A}$ \\
\hline $\mathrm{CaCO}_{3300} \mathrm{ppm}$ & $29.670 \mathrm{gh}$ & $30.250 \mathrm{fg}$ & $31.280 \mathrm{e}$ & 30.730 ef & $30.480 \mathrm{~B}$ \\
\hline Kaolin 1\% & 25.220 op & $25.460 \mathrm{n}-\mathrm{p}$ & $25.720 \mathrm{~m}-\mathrm{o}$ & $25.900 \mathrm{mn}$ & $25.570 \mathrm{E}$ \\
\hline Kaolin 2\% & $26.170 \mathrm{~m}$ & 26.8601 & $27.610 \mathrm{jk}$ & $27.180 \mathrm{kl}$ & $26.960 \mathrm{D}$ \\
\hline Kaolin 3\% & $16.580 \mathrm{z}$ & $19.950 \mathrm{w}$ & $18.740 \mathrm{x}$ & $17.530 \mathrm{y}$ & 18.200 I \\
\hline \multirow[t]{2}{*}{ Mean } & $23.470 \mathrm{C}$ & 24.420 B & $25.150 \mathrm{~A}$ & $25.080 \mathrm{~A}$ & \\
\hline & \multicolumn{5}{|c|}{ Proline content (mg/g d.w.) } \\
\hline Control & $0.605 \mathrm{a}$ & $0.568 \mathrm{~b}$ & $0.468 \mathrm{f}-\mathrm{h}$ & $0.3801-n$ & $0.506 \mathrm{~A}$ \\
\hline ADY $1 \%$ & $0.553 \mathrm{~b}$ & $0.521 \mathrm{~cd}$ & $0.488 \mathrm{e}$ & $0.456 \mathrm{~g}-\mathrm{j}$ & $0.505 \mathrm{~A}$ \\
\hline ADY $2 \%$ & $0.535 \mathrm{c}$ & $0.454 \mathrm{~h}-\mathrm{j}$ & $0.389 \mathrm{~lm}$ & $0.3791-n$ & $0.439 \mathrm{D}$ \\
\hline ADY 3\% & $0.467 \mathrm{f}-\mathrm{h}$ & $0.450 \mathrm{ij}$ & $0.386 \mathrm{~lm}$ & $0.366 \mathrm{n}$ & 0.417 F \\
\hline $\mathrm{CaCO}_{3} 100$ ppm & 0.482 ef & $0.444 \mathrm{i}-\mathrm{k}$ & $0.431 \mathrm{k}$ & $0.369 \mathrm{n}$ & $0.431 \mathrm{E}$ \\
\hline $\mathrm{CaCO}_{3} 200$ ppm & $0.458 \mathrm{~g}-\mathrm{i}$ & 0.3921 & 0.334 o & 0.320 o & $0.376 \mathrm{G}$ \\
\hline $\mathrm{CaCO}_{3} 300$ ppm & $0.511 \mathrm{~d}$ & $0.447 \mathrm{ij}$ & $0.447 \mathrm{ij}$ & $0.376 \mathrm{mn}$ & $0.445 \mathrm{D}$ \\
\hline Kaolin 1\% & $0.520 \mathrm{~cd}$ & $0.506 \mathrm{~d}$ & 0.474 ef & $0.456 \mathrm{~g}-\mathrm{j}$ & 0.489 B \\
\hline Kaolin 2\% & $0.521 \mathrm{~cd}$ & $0.512 \mathrm{~d}$ & $0.471 \mathrm{fg}$ & $0.453 \mathrm{~h}-\mathrm{j}$ & 0.490 B \\
\hline Kaolin 3\% & $0.519 \mathrm{~d}$ & 0.481 ef & $0.447 \mathrm{ij}$ & $0.440 \mathrm{jk}$ & $0.472 \mathrm{C}$ \\
\hline Mean & $0.517 \mathrm{~A}$ & 0.478 B & $0.434 \mathrm{C}$ & $0.400 \mathrm{D}$ & \\
\hline
\end{tabular}

Means having the same letter within a column or rows are not significantly differed at 0.05 level of probability according to Duncan's multiple range test.

growth, development, metabolism, etc. In the same manner soil water is critical to plant growth and development. It is the solvent in which soil nutrients are dissolved before they can be absorbed by plant roots. Also, water is the medium of transportation of solutes and is required in photosynthesis (Acquaah, 2009).

Our results show the effective role of spraying with $\mathrm{CaCO}_{3}$ especially under stress conditions. Such results were in harmony with those obtained by Gaballah et al. (2014) on sunflower, Patanè et al. (2018) on tomato and Silva et al. (2019) on Vitis labrusca L. In this regard, El-Khawaga (2013) reported that using calcium carbonate weekly at $2 \%$ under $60 \%$ of available water depletion improved productivity as well as saving irrigation water amount of Grand Naine banana plants. AbdelFattah (2013) proved that spraying with $\mathrm{CaCO}_{3}$ thrice with one month intervals reverse the harmful effects of water defect on Hibiscus rosa-sinensis L. for all studied traits especially plant height, stem diameter, leaves, stems and roots fresh and dry weights, root length, chlorophylls and carotenoids contents and reduced proline content. Also, Ramadan and Omar (2017) concluded that the treatment of $80 \%$ replenishment of evaporation within $3 \% \mathrm{CaCO}_{3}$ was the best combination and it could be recommended for cabbage (c.v. Balady).

Results regarding the positive effect of active dry yeast (wither under normal or stress conditions) were in harmony with those obtained by El-Sayed $\boldsymbol{e t}$ al. (2010) on Spathiphyllum wallisii; Abd El-Kafie 
et al. (2010) on tuberose; Hanafy et al. (2012) on Schefflera arboricola; El-Sayed et al. (2015) on Peperomia obtusifolia; El-Mahrouk et al. (2016) on Adhatoda vasica; El-Naggar et al. (2016) on Anthurium andreanum; Nofal et al. (2016) on Calendula officinalis; Abdel-Kader et al. (2016) on Magnolia grandiflora and Abdou et al. (2018) on Gladiolus grandiflorus. Hammad and Ali (2014) reported that yeast extract at $6 \mathrm{~g} / \mathrm{l}$ produced the highest leaf area of wheat plants subjected to drought (80\% depletion of available soil water).

Also, this study showed that calcium carbonate was more effective than active dry yeast extract and kaolin under water stress conditions in most cases. This result was in harmony with those obtained by Ramadan and Omar (2017) who suggested that calcium carbonate $\left(\mathrm{CaCO}_{3}\right)$ can prevent stomata from opening fully by affecting stomatal guard cells and this led to decreasing losses of water vapor. Also, Abdel-Fattah (2013) interpreted such positive role of spraying $\mathrm{CaCO}_{3}$ as anti-transpirant under water deficit conditions to the increase in $\mathrm{Ca}^{+}$ concentration in plant tissues as a result to spraying with $\mathrm{CaCO}_{3}$. This accumulated ion may play a fundamental role in facilitating high turgor maintenance under water deficit conditions. When diluted concentrations of $\mathrm{CaCO}_{3}$ was applied, the white suspension can penetrate leaves through stomata, increasing the photosynthetic activity of the plant in relation to the increased level of $\mathrm{CO}_{2}$ deriving from the calcium carbonate (Attia et $\boldsymbol{a l}$. 2014). Results obtained by Silva et al. (2019) showed that films formed by spraying with either $\mathrm{CaCO}_{3}$ or $\mathrm{CaO}$ were efficient to provide artificial shading, the temperature of the leaves was significantly reduced in plants with these films, which also provided greater efficiency to control the energy absorption and the electrons fluxes energized by the photosystems and the electron transport chain.

The role of yeast under dehydration conditions couldn't be neglected. Dehydration conditions lead to the accumulation of reduced photosynthetic electron transport components that can reduce molecular oxygen and give rise to the production of reactive oxygen species (ROS) such as superoxide and hydroxyl radicals as well as hydrogen peroxide $\mathrm{H}_{2} \mathrm{O}_{2}$, thus causing oxidative damage in chloroplasts. In yeast cells, different types of enzymatic systems (i.e. catalase) have been found, catalase is an essential enzyme in the decomposition of such intracellular ROS such as $\mathrm{H}_{2} \mathrm{O}_{2}$ (Petrova et al.,
2002) and this in turn led to mitigate the harmful effect of water deficit.

In conclusion irrigation water of Cyperus alternifolius could be reduced by $25 \%$ without reduction in quality and atheistic value by irrigating plants planted in 25-cm-pots at 75\% WHC two times/week and spraying them with $\mathrm{CaCO}_{3}$ at 200 ppm monthly.

\section{REFERENCES}

Abd El-Kafie, O.M.; Hamza, A.M.; El-Hindi, K.H. and Abd El-Baset, M.M. (2010). Influence of phosphorus, potassium and yeast nutrition on growth, flowering and chemical composition of tuberose. J. Plant Production, 1(3):431-449.

Abdel-Fattah, G.H. (2013). Response of waterstressed rose of China (Hibiscus rosa-sinensis L.) plant to treatment with calcium carbonate and Vapor Gard anti-transpirants. J. App. Sci. Res., 9 (6):35663572 .

AbdelKader, H.H.; El-Boraie, E.A.H.; Hamza, A.M. and Badawya, M.F.R. (2016). Effect of mineral fertilization with some growth regulators on growth of magnolia grandiflora L. seedling. I. Effect on vegetative growth. J. Plant Production, Mansoura Univ., 7 (4): 401 - 407.

Abdou, M.; Badran, F.; Ahmed, E.; Taha, R. and Abdel-Mola, M. (2018). Effect of compost and some natural stimulant treatments on: I. vegetative growth and flowering aspects of (Gladiolus grandiflorus cv. Peter Pears) plants. Scientific Journal of Flowers and Ornamental Plants, 5(2):105114.

Abou-Khaled, A.; Hagan, R.M. and Davenport, D.C. (1970). Effects of kaolinite as a reflective antitranspirant on leaf temperature, transpiration, photosynthesis, and water-use efficiency. Water Resour. Res., 6(1):280-289.

Acquaah, G. (2009). Horticulture Principles and Practices. Fourth Edition. Pearson Prentice Hall, New Jersey, USA, 760 p.

Attia, F.; Martinez, L. and Lamaze, T. (2014). Foliar application of processed calcite particles improves leaf photosynthesis of potted Vitis vinifera L. (var. 'Cot') grown under water deficit. J. Intern. des Sci. de la Vigne et du Vin, 48:237-245.

Azizi, A.; Hokmabadi, H.; Piri, S. and Rabie, V. (2013). Effect of kaolin application on water stress in pistachio cv. Ohadi. Journal of Nuts, 4(4):9-14.

Barnett, J.A.; Payne, R.W. and Yarrow, D. (1990). Yeast Characteristics and Identification, second ed. Press, Cambridge Univ., London, UK, $1012 \mathrm{p}$. 
Bates, L.S.; Waldren, R.P. and Teare, I.D. (1973). Rapid determination of free proline for water stress studies. Plant Soil, 39:205-207.

Brickell, C. (1997). The American Horticultural Society A-Z Encyclopedia of Garden Plants. DK Publishing, Inc., New York, USA, 1092 p.

Brooks, K.N. (1970). The Effects of Antitranspirant Chemicals on the Transpiration and Physiology of Tamarix Species. Ph.D. Thesis, Arizona Univ., USA, 84 p.

Brown, L.V. (2002). Applied Principles of Horticultural Science, Second Edition. ButterworthHeinemann, UK, 322 p.

Deàk, T. (2003). Yeasts: in Encyclopedia of Food Sciences and Nutrition (ed. Caballero, B.). Academic Press, USA, 6000 p.

Dobbs, A.J.; Peleg, M.; Mudgett, R.E. and Rufner, R. (1982). Some physical characteristics of active dry yeast. Powder Technology, 32(1):63-69.

Duncan, D.B. (1955). Multiple range and multiple F test. Journal of Biometrics, 11:1-42.

El-Khawaga, A.S. (2013). Response of Grand Naine banana plants grown under different soil moisture levels to anti-transpirants application. Asian J. Crop Science, 5(3):238-250.

El-Mahrouk, E.M.; Abd El-Gayed, M.E. and AbouKamar, A.N. (2016). Response of Adhatodavasica L. grown in different soils to some fertilization treatments. J. Agric. Res. Kafr ElSheikh Univ., 42(1):216-239.

El-Naggar, A.H.; Esmaiel, N.M. and El-Naggar, A.A. (2016). Effect of mineral and bio- fertilization on vegetative growth and flowering of Anthurium andreanum, L. plants under greenhouse conditions. Alexandria Science Exchange Journal, 37(1):1-9.

El-Said, E.M. (2015). Effect of irrigation intervals and some anti-transpirants on growth, yield and fruit quality of eggplant. J. Plant Production, Mansoura Univ., 6 (12): 2079- 2091.

El-Sayed, B.A.; Abdel-Moniem, M.A. and Shahin, S. M. (2010). Improving efficiency of NPK fertilizer for Spathiphyllum plant by using active dry yeast at various levels. J. Biol. Chem. Environ. Sci., 5(4):1-12.

El-Sayed, B.A.; Shahin, S.M. and Abdel-Moniem, A.M. (2015). Response of Peperomia obtusifolia (L.) A. Dietr cv. variegata plant to some fertilization treatments. Scientific Journal of Flowers and Ornamental Plants, 2(1):127-134.

Ferreira, T. and Rasband, W.S. (2012). ImageJ User Guide-IJ-1.46. http://imagej.nih.gov/ij/docs/guide.
Gaballah, M. S.; Shaaban, S. M. and Abdallah, E. F. (2014). The use of anti-transpirants and organic compost in sunflower grown under water stress and sandy soil. International Journal of Academic Research, 6(6):211-215.

Gomaa S.M.; Khalifa, E.M. and El-Nemr, M.K. (2005). Water regime and cucumber productivity under mulch and non-mulch conditions. The $13^{\text {th }}$ Conference of the Misr Society of Agric. Eng. "Role and Horizone of Agricultural Engineering in the Contemporary World", 14-15 December, 870-886.

Gomez, K.A. and Gomez, A.A. (1984). Statistical Procedures for Agricultural Research. John Wiley \& Sons, New York, USA, 680 p.

Hammad, S.A. and Ali, O.A. (2014). Physiological and biochemical studies on drought tolerance of wheat plants by application of amino acids and yeast extract. Annals of Agricultural Sciences, 59(1):133145 .

Hanafy, M.S.; Saadawy, F.M.; Milad, S.M.N. and Ali, R. M. (2012). Effect of some natural extracts on growth and chemical constituents of Schefflera arboricola plants. Journal of Horticultural Science \& Ornamental Plants, 4(1):26-33.

Herbert, D.; Phipps, P.J. and Strange, R.E. (1971). Chemical Analysis of Microbial Cells. In Methods in Microbiology, Academic Press, London (UK) and New York (USA), 5:209-344.

Khalil, S.E.; Hussein, M.M. and Da Silva, J.T. (2012). Roles of anti-transpirants in improving growth and water relations of Jatropha curcas L. grown under water stress conditions. Plant Stress, $6(1): 49-54$

MSTAT Development Team (1989). MSTAT user's guide: a microcomputer program for the design management and analysis of agronomic research experiments. Michigan State University, East Lansing, USA

Mukherjee, S.; Paliwal, R. and Pareek, S. (2004). Effect of water regime, mulch and kaolin on growth and yield of ber (Ziziphus mauritiana Lamk.). J. Horti. Sci. and Biotech., 79(6): 991-994.

Nagodawithana, W.T. (1991). Yeast Technology. Universal foods corporation Milwaukee, Wisconsin. Van Nostrand Reinhold, New York, 273 p.

Nakano, A. and Uehara, Y. (1996). The effects of kaolin clay on cuticle transpiration in tomato. In International Symposium on Plant Production in Closed Ecosystems 440 (pp. 233-238).

Nofal, F.H.; El-Segai, M.U. and Seleem, E.A. (2016). Influence of yeast natural extract on growth, flowering, yield and some anatomical structure of marigold (Calendula officinalis L.) plant. J. Plant Production, Mansoura Univ., 7(2):177-183. 
Noor El-Deen, T.M.; Elbohy, N.F.S.; Attia; K.E. and Mokhtar, N.Y.O. (2018). Synergistic impact of soil mulching and kaolin concentration on Zinnia elegans plants grown under different irrigation levels. Bull. Fac. Agric., Cairo Univ., 69(4):403425.

Oakes, A.J. (1990). Ornamental Grasses and Grasslike Plants. Van Nostrand Reinhold, New York, USA, 614 p.

Pallardy, S.G. (2008). Physiology of Woody Plants. Third edition. Academic Press, California,USA, 454 p.

Patanè, C.; Pellegrino, A. and Di Silvestro, I. (2018). Effects of calcium carbonate application on physiology, yield and quality of field-grown tomatoes in a semi-arid Mediterranean climate. Crop and Pasture Science, 69(4):411-418.

Petrova, V.Y.; Rasheva, T.V. and Kujumdzieva, A.V. (2002). Catalase enzyme in mitochondria of Saccharomyces cerevisiae. Electronic Journal of Biotechnology, 5(1):11-12.

Puterka, G.J.; Glenn, D.M.; Sekutowski, D.G.; Unruh, T. R. and Jones, S. K. (2000). Progress toward liquid formulations of particle films for insect and disease control in pear. Environmental Entomology, 29(2):329-339.
Ramadan, A.Y. and Omar, M.M. (2017). Effect of water regime and anti-transpirants foliar on production and yield of cabbage in summer season. Egypt. J. Soil Sci., 57(4):467-476.

Schrader, L.E. (2011). Scientific basis of a unique formulation for reducing sunburn of fruits. HortScience, 46:1-11.

Silva, P.S.O.; Oliveira Junior, L.F.G.; de Mattos, E.C.; dos Santos Maciel, L.B.; dos Santos, M.P. F., Sena, E.D.O.A., and Fagundes, J.L. (2019). Calcium particle films promote artificial shading and photoprotection in leaves of American grapevines (Vitis labrusca L.). Scientia Horticulturae, 252:7784.

Wellburn, A.R. and Lichtenthaler, H. (1984). Formulae and program to determine total carotenoids and chlorophylls a and b of leaf extracts in different solvents. Adv. Agricul. Biotechn., 2(1):9-12.

WWDR (2018). The United Nations World Water Development Report: Nature-Based Solutions for Water. United Nations Educational, Scientific and Cultural Organization, France, 139 p. 